\title{
NOVI PRILOG ŽIVOTOPISU JOSIPA PL. VANCAŠA (1859. - 1932.): OBITELJSKI TEMELJI, UZORI I POTICAJI DRUŠTVENOG I KULTURNOG DJELOVANJA
}

Jelena BOŽIĆ

JNU Institut za zaštitu i ekologiju Republike Srpske

Banja Luka, Bosna i Hercegovina
UDK: 72:929 Vancaš, J.

DOI: $10.21857 /$ ygjwrcdvjy

Izvorni znanstveni rad

Prihvaćeno: 11. ožujak 2020.

Na temelju novih saznanja iz arhivskog gradiva, onodobnog tiska i literature, u ovom se članku po prvi puta sistematiziraju i koreliraju poznati podatci s dosad neobrađenim činjenicama iz obiteljske povijesti arhitekta Josipa pl. Vancaša. Identificirani su istaknuti članovi obitelji na vertikalnoj i horizontalnoj razini koji su opredjeljujuće utjecali na njegovo izgrađivanje sustava vrijednosti i profiliranje njegova karaktera, pregnuća i dosege. Potpunije poznavanje Vancaševa životopisa pojašnjava njegovu po mnogočemu iznimnu osobnost, a time i zasluge za kulturni i gospodarski razvitak Sarajeva, nedjeljivo prisutne u modernoj hrvatskoj povijesti.

Ključne riječi: Josip pl. Vancaš, obitelj, društveno i kulturno djelovanje, Hrvatska, Sarajevo, Austro-Ugarska.

\section{UVOD}

Istraživanja predstavljena u ovome članku potaknuta su potrebom sustavnijeg prikaza čimbenika koji su utjecali na iznimno bogat životopis znamenitog arhitekta Josipa pl. Vancaša (1859. - 1932.), kako bi se upotpunila slika o njegovoj izvanrednoj osobnosti. O Vancaševu opsežnom, vrijednom i slojevitom stručnom stvaralaštvu u povijesti arhitekture Bosne i Hercegovine objavljen je niz znanstvenih radova i jedna monografija. ${ }^{1}$ Bio je ne samo najznačajniji i najutjecajniji arhitekt, $s$ najprimjetnijim opusom u ukupnoj povijesti ove zemlje, nego i pokretač i nositelj svih važnijih zbivanja u javnom, društvenom, kulturnom i gospodarskom životu od doseljenja u Sarajevo 1883. do svršetka Prvog svjetskog rata. Iako su Vancaševe neprolazne zasluge u temeljima moderne društvene povijesti $\mathrm{BiH}$, njegov osobni profil ostao je nedovoljno poznat.

Kao nužan okvir povezivanja odnosa u sustavu znanstvenog promišljanja i shvaćanja jednog vrijednog životnog djela u njegovoj širokoj interakciji s

Jelena Božıć, Arbitekt Josip Vancaš. Značaj i doprinos arbitekturi Sarajeva, Zavod za udžbenike i nastavna sredstva, I. Sarajevo, 2006. 
vremenom i ljudima, rad se najprije fokusira na obiteljsko okruženje. Istražene relevantne historijske činjenice o istaknutim članovima obitelji Vancaš i s njima vezanih obitelji, svojevrsna su kronika tadašnjih društvenih zbivanja u smjeru osnaživanja hrvatske nacionalne svijesti, neodvojive od života i rada Josipa Vancaša. Ranija stajališta sada se dodatno istražuju, preispituju i s brojnim novim nalazima upotpunjuju. Krajnji cilj povezivanja naizgled udaljenih manje poznatih i nepoznatih povijesnih činjenica je obiteljsko kontekstualiziranje djelovanja Josipa pl. Vancaša u Bosni i Hercegovini, a napose u Sarajevu, gdje je stanovao. Nakon više od četiri stoljeća nadmoći islama i izrazito nepovoljnih uvjeta socijalno-pravne nejednakosti, s austrougarskom okupacijom (1878.) dolazi do naglih političkih i ubrzanih kulturnih, socijalnih i gospodarskih promjena svojstvenih razdoblju ranog kapitalizma i nastanka građanskog društva.

Istraživanje provedeno metodologijom povijesnih znanosti, utemeljeno je na arhivskoj građi, onovremenom tisku koji prilike i događanja interpretira iz rakursa suvremenika te objavljenoj historiografskoj građi, znanstvenim i stručnim člancima. Dragocjeni i pouzdani izvori podataka su Autobiografska zabilješka Josipa Vancaša ${ }^{2}$ i nekrolog Alfreda Makanca, kojemu je Vancaš bio blizak prijatelj i vjenčani $\mathrm{kum}^{3}{ }^{3}$ te onodobni tisak. Sarajevski list, službeno glasilo Zemaljske vlade Bosne i Hercegovine, nije propuštao ni jednu bitnu vijest o Vancašu, zbog čega je dugotrajno iščitavanje svih brojeva rezultiralo pouzdanim podatcima nezamjenjive vrijednosti. Pretraživanjem digitaliziranih novina u Kraljevini Hrvatskoj i Slavoniji, ${ }^{4}$ pronađen je niz dragocjenih historijskih podataka o istaknutim članovima obitelji Vancaš, koji su do sada bili neobrađeni i najvećim dijelom posve nepoznati. S novim historijskim činjenicama upotpunjuje se Vancašev životopis, što omogućuje bolje razumijevanje i valoriziranje njegova značaja i dugoročnog utjecaja. Slijedeći baštinjene obiteljske vrijednosti i duh vlastite epohe, djelovanjem u

2 Dalje: Autobiografska zabilješka. U vrijeme ranijih istraživanja (1988.) bila je pohranjena u arhivu Republičkog zavoda za zaštitu spomenika kulture i prirode $\mathrm{BiH}$ u Sarajevu.

3 Alfred Makanec, Josip pl. Vancaš Požeški, Katolički tjednik, br. 52, 25. 12. 1932., 2 - 4. Alfred Makanec (1879. - 1945.) hrvatski je povjesničar i publicist, član hrvatske domoljubne i kulturne Družbe „Braća Hrvatskog Zmaja“ (u kojoj je kao Zmaj Požeški od 1926. Josip pl. Vancaš član, a onda i počasni član). Njegov otac dr. Julije bio je sarajevski gradski fizik, zastupnik sarajevskog Gradskog vijeća (kao i Vancaš) te vlasnik tiskare Bosnische Post i istoimenih novina, a sin, dr. Julije Makanec (1904. - 1945.) bio je hrvatski filozof i političar te ministar nastave u Vladi Nezavisne Države Hrvatske (1943. do 1945.)

4 Portal Stare hrvatske novine, izrađen 2010. u okviru projekta Hrvatska kulturna baština Ministarstva kulture Republike Hrvatske, http://dnc.nsk.hr/Newspapers/Default.aspx, posjećeno tijekom 2019. godine. 
kulturnim, društvenim, gospodarskim i političkim ${ }^{5}$ procesima modernizacije zemlje i hrvatskih nacionalno-integracijskih procesa, stekao je velike i trajne osobne zasluge za promicanje hrvatskog kulturnog identiteta u onodobnim društveno-politički nepovoljnim uvjetima.

\section{OBITELJ - TEMELJI, UZORI I POTICAJI}

Obiteljsko okruženje, općenito, sustav je u kojem su ponašanje i odnos među članovima obitelji u uzajamno-povratnoj međuovisnosti. Potpora i poticaji roditelja i ostalih članova obitelji imaju nenadomjestivu ulogu za odgoj i pravilan psihološki razvoj osobnosti. Promicanjem dobrobiti i pozitivnog sustava visoke razine podrške, obitelj definira temeljne psihosocijalne odlike i sposobnosti, moralni i religijski identitet, a s time i ključne životne stavove, ukuse i kulturni kapital djeteta. Sve to $u$ odrasloj dobi utječe na stupanj profesionalnog i životnog postignuća, socijalno ponašanje i prilagodljivost, povratno djelujući na jačanje obiteljske kohezije. Skladni obiteljski odnosi i jaka emocionalna povezanost $s$ roditeljima, braćom i sestrama, kao i članovima šire obitelji, u temeljima su formiranja karaktera Josipa pl. Vancaša te razvijanja njegovih darovitosti, izražavanja osobnosti i razvitka svih potencijala kao zalog uspješnog funkcioniranja. Obiteljski svjetonazori, društveni ugled i reputacija oca Antuna, pravnika, strica Janka, župnika, starijeg brata Alekse, odvjetnika, a osobito strica dr. Alekse, liječnika, zasigurno su bili motivirajućim uzorima njegova u svemu odgovornog i moralnog ponašanja. U takvom obiteljskom ozračju rano je stekao marljivost i osobitu sklonost k obrazovanju. Situirana obitelj, naglašeno čvrstih i kvalitetnih međuodnosa, izrazitim kršćanskim svjetonazorom i $s$ nizom intelektualnih poticaja pružila je uzore i visoke standarde za formiranje nesputane osobnosti i dosege sveukupno najistaknutijeg kulturnog i javnog djelatnika promatranog vremena i prostora.

Josip Vancaš odvjetak je ugledne hrvatske obitelji iz Požege, kojih je postojbina Farkašić na Kupi. ${ }^{6}$ Prema temeljito provedenim istraživanju Josipa Buturca,

5 Kako je riječ o složenoj temi, politički angažman Josipa Vancaša zahtijeva zasebno istraživanje i sustavnu obradu. U članku je ova sastavnica njegova rada izložena u opsegu čija je nakana da pruži cjelovit pregled uvjeta, prilika i društvenih procesa u kojima je ostvario značajne dosege. Među historiografskim naslovima vezanim uz političku djelatnost Josipa Vancaša osobito se izdvaja kapitalno monografsko djelo: Zoran GRIJAK, Politička djelatnost vrhbosanskog nadbiskupa Josipa Stadlera, Zagreb, 2001.

6 Dr. Rudolf Horvat, Arhitekt Josip pl. Vancaš, Hrvatska revija, god. VI, br. 3, 1933., 193; Dr. Leander BRozović, Dr. Aleksa Vancaš (1808. - 1884.), Liječnički vjesnik, god. LXIII, br. 4, Zagreb, 1941., 246, http://library.foi.hr/casopisi/vel/S01101/1941/1941_00004.pdf., posjećeno 15.3. 2019. 
obitelj Vancaš u Požegi je bila nastanjena samo šest godina, od 1816. do 1822. godine. ${ }^{7}$ Međutim, dr. Brozović, autor članka o dr. Aleksi Vancašu (Josipovu stricu), navodi da mu je otac bio gospoštiljski činovnik i da je umro u Požegi $1834 .{ }^{8}$ Prilog tomu je i podatak da je njegov otac Antun sa svojim zakonitim potomstvom od cara Franje Josipa 23. kolovoza 1880. dobio ugarsko plemstvo na prijedlog ugarskog ministra Bele Orczyja, a u znak priznanja za dugogodišnje revnosno i uspješno djelovanje kao savjetnika i direktora Hrvatsko-slavonskih Pošta, uz istodobno dopuštenje korištenja opisnog naslova Požešk $i .{ }^{9}$ Do obiteljske plemićke titule, a kasnije i dodatnog naslova Požeški, Josip pl. Vancaš veoma je držao te ga onodobni bosansko-hercegovački tisak redovito tako i navodi.

Rođen je 22. ožujka 1859. u Šopronu, gdje mu je otac tada službovao. U braku njegovih roditelja, oca Antuna pl. Vancaša Požeškog (22. veljače 1816. - 11. srpnja 1889.) i majke Marije pl. Vancaš rođ. Griller (1821. - 2. siječnja 1879. $)^{10}$ rođeno je sedmoro djece: najprije sin Koloman, rođen 1845., a preminuo već 1846 . godine u kojoj im se rodila najstarija kći Marija. Sin Aleksa (Alexa ${ }^{11}$ ) Viktor, rođen je 1849., Emilia $\left(\mathrm{Ema}^{12}\right)$ 1852., Josip 1859., Bela 1860., a 1867. godine najmlađi Antun (vidjeti Prilog 1. Rodoslovlje obitelji Vancaš).

ANTUN PL. VANCAŠ POŽEŠKI (22. veljače 1816. - Zagreb, 12. srpnja 1889.)

Bitne podatke iz životopisa Antuna Vancaša, od oca Janka ${ }^{13}$ (? - Požega, 4. travnja 1834. ${ }^{14}$ i majke Terezije rođ. Stöger ${ }^{15}\left(\right.$ ? - 17. kolovoza 1829.), ${ }^{16}$ nalazimo

7 Josip Buturac, Stanovništvo Požege i okolice 1700. - 1950., Zbornik za narodni životi običaje JAZU, knj. 43, Zagreb, 1967., 285, Digitalna zbirka HAZU, https://dizbi.hazu.hr/a/?pr=i\&id=21107. posjećeno 23. 5. 2019. Autor u Predgovoru navodi da su samo sigurni i vjerojatni iskazi ušli u ovaj prikaz, dok su nesigurni ispušteni.

8 U Autobiografskoj zabilješci Josip Vancaš navodi da mu je djed bio upravnik vlastelinstva u Požegi.

9 Adelsverleihungen, Syrmier Zeitung, br. 37, 12.9. 1880., 3; Adelstands - Erhebung, Syrmier Zeitung, br. 40, 3. 10. 1880., 2 (Vijest prenesena iz „Budapesti Közlöny“).

10 Marija Vancaš, Branislav (Osijek), br. 2, 3. 1. 1879., 2; Umrli godine 1879., Sriemski Hrvat (Vukovar), br. 2, 8. 1. 1880., 13.

11 Natpis na nadgrobnom spomeniku (Mirogoj, rkt odjel, polje 9, razred II/I, broj 36).

12 Natpis na nadgrobnom spomeniku (Mirogoj, GI odjel, polje 122A, razred II, broj 71).

13 Franjo Bılıć, Život Antuna Vancaša, Arte musices, br. 4, 1973, 131. Izvodeći Rodoslov obitelji Vancaš prema Jutarnjem listu od 6. 4. 1937., Bilić navodi da je ime Josipova djeda Janko Vancaš (Vanczass) i da je preminuo u Požegi, dok Brozović navodi da je ime oca Ivan i da je bio gospoštijski činovnik. S obzirom na to da se među njegovim nasljednicima ne pojavljuje ime Ivan, nego Janko, vjerojatnije je to njegovo ime ili je riječ o višečlanoj imenskoj formuli.

14 F. BiLIć, Život Antuna Vancaša, 131.

15 Dr. L. Brozović, Dr. Aleksa Vancaš (1808. - 1884.), 246.

16 F. BıLIĆ, Život Antuna Vancaša, 131. 
u podužem članku koji su prigodom njegova umirovljenja 1884. godine objavile Narodne novine. ${ }^{17}$ Prema ovome izvoru, pravne znanosti završio je u Zagrebu, iako Josip Vancaš u Autobiografskoj zabilješci navodi da ih je završio u Požunu (danas Bratislava, Slovačka). ${ }^{18}$ Iz članka dalje doznajemo da je nakon „izvrsno položenog odvjetničkog ispita“, 19 26. srpnja 1836. stupio u službu vrhovne poštanske uprave u Varaždinu kao „bezplatni zaprisegnuti vježbenik“. Godine 1843. imenovan je akcesistom poštanskog ureda drugog, a 1846. prvog razreda. U Zagreb je došao 1847. kao kontrolni oficijal vozne pošte, u kojem je svojstvu ubrzo premješten u Požun. Potom je 1850. imenovan poštanskim povjerenikom u Košicama i u istom svojstvu 1852. premješten u Šoprun, a već sljedeće godine napreduje na radno mjesto u poštanskom ravnateljstvu. Godine 1862. imenovan je privremenim upraviteljem poštanskog upraviteljstva u Velikom Varadinu, a 7. veljače 1864. ravnateljem Hrvatsko-slavonskih pošta u Zagrebu, gdje se s obitelji nastanio u sjedištu Pošte. Naslov kr. savjetnika podijeljen mu je 1872. godine. Nakon 48 godina „uzorite službe“, na vlastitu je molbu umirovljen 1884. godine. Poštarstvo u Hrvatskoj i Slavoniji kroz dva je desetljeća na mjestu ravnatelja unaprijedio „kako se ni slutiti nije moglo“ i bio „svijetao primjer revnosti, marljivosti i točnosti“. U odnosu na podređene bio je strog, ali s „osobitim taktom“ $i$ pravedan, brinući uvijek za njihove interese, ${ }^{20}$ zbog čega se "mogao pohvaliti tolikom iskrenom odanosti, tolikom, uprav pietetskom ljubavi svojih potčinjenih“. Na svečanom oproštajnom banketu, koji mu je priređen 2. siječnja 1885., tajnik ravnateljstva Pošta g. Kuna je, ističući njegove neprolazne zasluge, naveo „da se punim pravom može reći da je on poštarstvo kod nas stvorio i uredio“, postupajući „sa podčinjenim si osobljem kano otac sa svojom djecom, pa tim stekao ljubav ne samo poštarskih činovnika, nego i svih poštarah".21

Uz to je bio i politički angažiran, što potvrđuje novi podatak da se na drugim neposrednim izborima za Sabor 1861 . odrekao kandidature u pribićkom kotaru. ${ }^{22}$ Bio je snažno utemeljen $u$ katoličanstvu, kao istaknutom obilježju hrvatstva.

17 Gospodin Antun pl. Vancaš, Narodne novine, br. 289, 15. 12. 1884., 4.

18 Autobiografska zabilješka.

19 Cenzuru „kod visokog stola banskoga“ položio je 1837. Ilirske narodne novine, br. 78, 30. 9. $1837 ., 1$.

20 Potvrda te skrbi je i podatak da je poštu u Samoboru htio prenijeti na udovicu poštara „koja imade petero neobskrbljene djece. Barun Rauch znadiaše izraditi, da se pošta oduzme toj sirotinji..." (Mira Kolar-Dimitrijević, Kako su narodnjaci pobijedili na izborima 1871.? (Nepoznata brošura Ivana Mažuranića?), Povijesni prilozi, vol. 14, br. 14, 1995., 200, https://hrcak.srce.hr/107175, posjećeno 7. 11.2019.).

21 Oproštaj sa ravnateljem poštah gosp. Vancašem, Narodne novine, br. 2, 3. 1. 1885., 4.

22 M. Kolar-Dimitrijević, Kako su narodnjaci pobijedili, 200 (podn. nap. 150). 
Njegov je dom bio sastajalište iliraca, ${ }^{23}$ a nalazimo ga i među darovateljima za dogradnju zagrebačke prvostolne crkve. ${ }^{24}$

U članku prigodom umirovljenja navedeno je da će se nastaniti „u Budimpeštu kod svoje kćeri udate za viećnika prizivnoga suda g. Thyeria“. ${ }^{25}$ Posrijedi je njegova starija kći Marija (1846. - 1942.) udana za Alojza baruna Thierryja (Rijeka, 1845. - 1930.). ${ }^{26}$ Njegov brat Josip Franjo Alois barun Thierry (Rijeka, 1849. - Delnice, 24. listopada 1882. $)^{27}$ oženio je Marijinu sestru Emu (1852. - 30. siječnja 1942.). ${ }^{28}$

Antun pl. Vancaš Požeški preminuo je 11. srpnja 1889. u Zagrebu, ${ }^{29}$ gdje je na groblju Mirogoj pokopan u obiteljsku grobnicu s ranije preminulom suprugom Marijom i sinom Antunom. ${ }^{30}$

Visok očev društveni položaj i ugled zasigurno su u temeljima oblikovanja karaktera i osobnosti Josipa Vancaša, napose njegove ustrajnosti, odgovornosti i pune posvećenosti u svojem djelovanju. Takav je utjecaj na njega imala i baština njegovih stričeva, župnika Janka i liječnika Alekse.

\section{JANKO VANCAŠ (1805. - Zagreb, 17. rujna 1858.) ${ }^{31}$}

Stariji očev brat Janko bio je župnik kod Sv. Ane pod Turnom, začasni kanonik Stolne crkve Zagrebačke nadbiskupije ${ }^{32}$ te od lipnja 1851. vicearhiđakon $u$

23 M. Kolar-Dimitrijević, Kako su narodnjaci pobijedili, 200.

24 Izkaz p. n. gospode darovateljah i članovah družtva za dogradjenje prvostolne crkve zagrebačke, Narodne novine, br. 205, 7. 9. 1883., 4. Darovao je 10 for.

25 Oproštaj sa ravnateljem poštah gosp. Vancašem, Narodne novine, br. 2, 3. 1. 1885., 4.

26 Alojs Philipp Stephan Anton barun Thierry je nakon studija prava završenog 1867. u Zagrebu imenovan sudcem 1869. Od listopada 1871. kotarski je sudac u Delnicama, od 1875. sudac u Našicama, a od 27. travnja 1881. je sudac u Zagrebu. Predsjednik suda Kraljevine Mađarske u Budimpešti je od 23. svibnja 1883. do konca 1892., od kada je predsjednik suda u Rijeci. Ugarski barunat dodijeljen mu je u kolovozu 1918. (M. D., Thierry, http://www.cro-eu.com/forum/index. php?topic $=2825.0$, posjećeno 4. 9. 2018.).

Prema Biliću (Život Antuna Vancaša, 131), Marija i Alojz Thierry imali su dva sina: Fridrika i Franju. Pronađen je podatak da je Franjo - Franz Anton Ludwig barun Thierry rođen u Zagrebu 1871., a preminuo u Budimpešti 1942. (dr. Balázs Ábry, Franz Anton Ludwig barun Thierry, https://www.geni. com/people/FRANZ-Anton-Ludwig-barunThierry/6000000058028983947, posjećeno 20. 9. 2019.).

27 Najprije je sudski pristav u Krapini. (M. D., Thierry).

28 Ukopana je u grobnicu s kćeri Josipom Kukuljević Sakcinski (1876. - 1964.). Groblje Mirogoj, odjel GI, polje 122A, razred II, broj 71 .

29 Čitulja, Sarajevki list, br. 83, 14. 7. 1889., 3. Preminuo je „poslije podužeg bolovanja u 73. godini kralj. savjetnik i direktor pošte u miru Anton pl. Vancaš - Požeški, otac gragjanskom neimaru g. Josipu pl. Vancašu“.

30 Mirogoj, rkt odjel, polje 8, razred II/I, br. 34 .

31 Carsko-kr. službene Narodne novine, br. 213. 18. 9. 1858. Preminuo je u Zagrebu, nakon kratkog bolovanja. „Svi, koji su ga pobliže poznavali žale iskreno njegovu smèrt, jer je bio čoviek 
Jastrebarskom okrugu. ${ }^{33} \mathrm{U}$ „Objavljenju“ od 20. rujna 1856. za upražnjeno mjesto pučke učione u Krašiću potpisan je kao „podarcidjakon i nadziratelj učionah kotara Jastrebarskog ". ${ }^{44}$ Nalazimo i podatak da je na osnivačkoj sjednici 24. srpnja 1851. izabran za odbornika jastrebarske podružnice Gospodarskog družtva horvatsko-slavonskoga. ${ }^{35}$ Duboko prožet idejama iliraca, u više je navrata davao novčane priloge za Maticu ${ }^{36} \mathrm{i}$, kao i brat mu dr. Aleksa, bio njezin utemeljitelj. ${ }^{37} \mathrm{Sa}$ osjećajem za potrebite, nalazimo ga i među darovateljima žiteljima sela Lukovdol u karlovačkoj podžupaniji, koje je u požaru na Uskrs te godine sasvim izgorjelo. Darovao je 2 for, koliko i Općina Sv. Ane. ${ }^{38}$

\section{DR. ALEKSA VANCAŠ (Veleševec, 17. srpnja 1808. - Kostel kraj Pribića, 28. lipnja 1884.)}

Možemo reći da je najizravnija poveznica s djelovanjem Josipa Vancaša brat njegova oca, stric dr. Aleksa Vancaš (Veleševec, ${ }^{39}$ 17. srpnja 1808. - Kostel kraj Pribića, 28. lipnja 1884.). Kao ugledni intelektualac, zaslužni hrvatski rodoljub i

bogobojazljiv, pošten i dobra sèrca, zbog čega je bio obćenito štovan. Pokojnikovo tielo zakopat će se u Dolu sutra u 3 sata poslie podne..."

32 S natpisa na nadgrobnoj ploči: „Ovde leži telo Janka Vancaša, bivš. župnika kod Sv. Ane pod turnom, podjašprišta i St. crk. zagr. nadb. zač. kanonika u 53. god. dobe svoje dne 17. rujna 1858. umrvšega, koga plemenitog srdca radi oplakuju priatelji, sirotinja, rod i dom." I Josip Vancaš u autobiografskoj zabilješci navodi da je stric bio župnik u Sv. Jani kod Jastrebarskog.

33 Promjene u biskupii zagrebačkoj, Narodne novine, br. 133, 11. 6. 1851., 384.

34 Objavljenje (Dp. 114), Carsko - kr. službene narodne novine, br. 226, 1. 10. 1856., 756.

35 D. R. Narodni dom. Družtvo gospodarsko. III. Izvjestje o zavedenju podružnice jastrebarske. Narodne novine, br. 193, 23. 8. 1851., 559. Uz njegovo ime navedeno je da je „podjašprišt jastrebarski i župnik sveto-janski“.

36 Domorodni darovi, Ilirske narodne novine, br. 42, 24. 5. 1842., 165 (dar od 5 for.); V. B., Iz Zagreba, 31. Prosinca (Dec.) 1842. Ilirske narodne novine, br. 2, 7. 1. 1843., 5 („po drugi put 5 for.“).

37 Utemeljiteljski prilog uplaćivao se odjednom ili tijekom pet godina po 10 for., kako je i bio slučaj kod braće Janka i Antuna Vancaša (V. B., Iz Zagreba, 10. Siečnja (Jan.) - Rodoljubivi darovi, Novine horvatsko-dalmatinsko-slavonske, br. 4, 11. 1. 1845., 13). Ovdje još treba podsjetiti da je iznos 50 for. srebra odgovarao petomjesečnoj plaći činovnika srednjeg ranga. (Josip BRLEKović, Članstvo Matice hrvatske u prošlosti i sadašnjosti, http://www.matica.hr/omatici/Kratka\%20povijest\%20 organiziranja\%20i\%20ustrojstva\%20Mati\%C4\%8Dina\%20\%C4\%8Dlanstva\%20(1842-2014)/, posjećeno 15. 9. 2018.).

38 Akt br. 3647/1851. od 30. svibnja 1851., potpisan u Zagrebu od Josipa Bunjevca, c. kr. vrhovnog župana. Narodne novine, br. 132, 10. 6. 1851., 380.

39 U većini se izvora kao mjesto njegova rođenja navodi Požega, ali je, s obzirom na već spomenuta istraživanja Josipa Buturca, vjerojatniji ovaj navod koji nalazimo i u natuknici: „Vancaš, Aleksa“, Hrvatska enciklopedija, mrežno izdanje, Leksikografski zavod Miroslav Krleža, http://www. enciklopedija.hr/Natuknica.aspx?ID=63816., posjećeno 17.9. 2018. 
ilirac, značajan za povijest medicine u Hrvatskoj, široko is uspjehom angažiran na stručnom, gospodarskom, društvenom, kulturnom i političkom polju, nedvojbeno je imao veliki utjecaj na smjerove, obujam i dosege angažiranja arhitekta Vancaša.

Pučku školu i franjevačku gimnaziju završio je u Požegi, a VII. i VIII. razred u Budimpešti. ${ }^{40}$ Obranom inauguralne disertacije aktualne teme De rabie na Sveučilištu u Pešti 1832., koju je posvetio svojemu „ujaku skrbniku Antonu Stögeru“, 41 promoviran je u zvanje "doktora medicine i kirurgije i magistra očarstva““22 Liječničku praksu započeo je „negdje u gornjoj Ugarskoj“, ${ }^{43}$ a 1834. seli u Zagreb, gdje je tada bilo malo liječnika. ${ }^{44}$ Od 1836 . je počasni, ${ }^{45}$ od $1842 .{ }^{46}$ do 1851. prvi fizik zagrebačke varmeđe (županije), a potom vrhovni zemaljski liječnik (protomedik) do 1860., kada je na vlastiti zahtjev umirovljen. ${ }^{47}$

Dr. Aleksa mnogo je pridonio strukovnom organiziranju i djelovanju. S grupom liječnika se još koncem 30-ih godina preko godinu dana redovito sastajao razmjenjujući iskustva i diskutirajući aktualna strukovna i staleška pitanja, pa ih se smatra pretečama Zbora liječnika. ${ }^{48}$ Godine 1845. dr. Aleksa i kolege osnovali su Družtvo lječiteljah u Zagrebu (Zagrebačko liečničkog družtvo), ${ }^{49}$ koje je

40 L. Brozović, Dr. Aleksa Vancaš, 246.

41 L. Brozović, Dr. Aleksa Vancaš, 247. Moguće je da je ujak bio skrbnik i mlađem bratu Antunu, Josipovu ocu, koji je imao samo osam godina kada mu je umrla majka, a s 13 godina ostao je i bez oca. Njihov najstariji brat Janko već je bio župnik.

42 Dissertatio medica De rabie, quam annuente inclyta Facultate medica pro doctoris medicinae laurea in alma ac Cel. regia Univ. Pestiensi consequenda conscripsit Alexius Vanczáss, Croata Zagrabiensis, Artis ocularis magister. These adnexae publice defendetur in Palato Reg. Universitatis maiori M. Augusto 1832. Budae: Typis Typogr. regiae Universit. Hungaricae, 1832., digitalno izdanje, https://books.google.ba/books?id=PLpUAAAAcAAJ\&pg=PA1\&source=gbs_ toc_r\&cad=3\#v=onepage \&q\&f=false (posjećeno 18. 11. 2019.). Pored latinskog jezika, do 60-ih godina 19. st. službenog u javnom političkom životu i hrvatskoj znanosti, sudeći prema korištenoj literaturi, vladao je francuskim, engleskim i, naravno, njemačkim, jezikom, koji je u to vrijeme bio općeprihvaćen u hrvatskoj izdavačkoj djelatnosti i kod građanstva. Također je vladao i mađarskim jezikom, jer je u Ugarskoj nekoliko godina živio, obrazovao se i radio nakon završetka školovanja.

43 L. Brozović, Dr. Aleksa Vancaš, 247.

44 Vladimir Dugački, Željko KrZnARIĆ, Hrvatski liječnički zbor od 1874. do 2014., Zagreb, 2014., 26, http://www.hlz.hr/pdf/knjiga-hlz.pdf., posjećeno 8. 10. 2018. Pronađen je i podatak da je dr. Vancaš u Zagrebu živio već od 1830. (Dr. Aleksa Vancaš, Narodne novine, br. 148, 28. 6. 1884., 4).

45 L. Brozović, Dr. Aleksa Vancaš, 247.

46 Iz Zagreba, Ilirske narodne novine, br. 45, 4. 6. 1842., 177.

47 Dr. Aleksa Vancaš, Liečnički vjestnik, br. 10, 1943., 303 - 305, https://library.foi.hr/m8/ S01101/1943/1943_00010.pdf., posjećeno 22.9. 2018.

48 Vladimir Ćepulić, Kratka povijest Zbora liječnika Hrvatske, Slavonije i Medumurja, Zagreb, 1937., 3, http://library.foi.hr/knjige/knjiga.aspx?C=2587\&broj=1, posjećeno 12. 6. 2018. Osim dr. Alekse, tada županijskog fizika, članovi Zbora bili su i tadašnji protomedik Daubach-Doljski, gradski fizik Krieger i izvjestan broj liječnika.

49 V. DUGAČKI, Ž. KRZNARIĆ, Hrvatski liječnički zbor od 1874 do 2014., 26. 
djelovalo do $1850 .^{50} \mathrm{~s}$ temeljnom zadaćom zaštite javnog zdravlja i staleških interesa liječnika. Iz sačuvanog zapisnika doznajemo da je dr. Vancaš izabran za predsjednikaZemaljske ankete za uređenje zdravstva. ${ }^{51}$ Prihvaćeni Prijedlog 1850. tiskan je kao knjižica Osnova za uređenje zdravničkoga upraviteljstva u krunovini Hérvatskoj i Slavoniji, čiji su autori dr. Aleksa Vancaš, dr. Aleksa Rakovac i dr. Lavoslav Schönstein. ${ }^{52} \mathrm{Uz}$ preporuke za zaštitu i unaprjeđenje javnog zdravlja, istaknuta je i potreba osnivanja medicinskog fakulteta za školovanje liječnika, kirurga i veterinara te primaljske škole na hrvatskom jeziku u Zagrebu, ali to nije naišlo na razumijevanje vlasti. ${ }^{53}$

I nakon umirovljenja dr. Aleksa nastavio je rad oko strukovnog organiziranja liječnika u gradu i zemlji. Tako je jedan od osnivača Sbora liečnika kraljevina Hrvatske i Slavonije u Zagrebu (26. veljače 1874.), ${ }^{54}$ koji je poticao promicanje zdravstva i razvitak medicinske znanosti zalažući se za osnivanje medicinskog fakulteta na kr. Sveučilištu u Zagrebu. ${ }^{55} \mathrm{Na}$ prijedlog svojega prethodnika, dr. Rakovca, dr. Aleksa bio je predsjednik Zbora od 15. srpnja 1882. do kraja života, iako je bio zabilježen kao predsjednik sve do izbora novog predsjednika, 1885. ${ }^{56}$ Od samoga početka, Zbor je na svojim sastancima raspravljao o suvremenim znanstvenim postignućima i, na traženje vlasti, davao mišljenja o stručnim, staleškim i organizacijskim pitanjima iz medicine. U tome je smislu bilo od značaja imenovanje dr. Vancaša 1875. predsjednikom Zemaljskog zdravstvenog vijeća ${ }^{57}$ savjetodavnog tijela kraljevske Zemaljske vlade. ${ }^{58}$

50 Vesna Ćosıć, Demografske i javnozdravstvene odrednice razvoja porodništva $i$ primaljstva $u$ Slavonskom Brodu tijekom 19. stoljeća, doktorski rad, Medicinski fakultet Sveučilišta u Zagrebu, Zagreb, 2016., 15, http://medlib.mef.hr/2607/1/Cosic_Vesna.pdf., posjećeno 9. 11. 2019.

51 V. Ćepulić, Kratka povijest Zbora liječnika, 3; L. Brozović, Dr. Aleksa Vancaš, 246.

52 „Zapisnik delah perve obćenite skupštine lečnikah krunovine Hrvatske i Slavonie“ od 14. lipnja 1850., u: V. ĆEPulić, Kratka povijest Zbora liječnika, 8; Dr. Lujo Thaller, Povijest medicine u Hrvatskoj $i$ Slavoniji od god. 1770. do 1850., Karlovac, 1927., 108, http://library.foi.hr/knjige/ knjiga1.aspx? $\mathrm{B}=1 \& \mathrm{C}=\mathrm{X} 00604$, posjećeno 17.6. 2019.

53 V. Ćosıć, Demografske i javnozdravstvene odrednice razvoja porodništva i primaljstva u Slavonskom Brodu tijekom 19. stoljeća, 18.

54 U znak sjećanja, 26. veljače obilježava se kao hrvatski Dan liječnika.

55 Izjava Sbora liečnika u Zagrebu, Narodne novine, br. 121, 26. 5. 1888., 14. Dr. Vancaš predsjedavao je prvom godišnjom i izbornom skupštinom Zbora, 3. kolovoza 1874. (V. DUGAčKI, Ž. KRZNARIĆ, Hrvatski liječnički zbor od 1874. do 2014., 11).

56 V. ĆEPUliĆ, Kratka povijest Zbora liječnika, 3 - 4; Biserka BEliCzA, Dubravko OrLIĆ, Hrvatski liječnički zbor: predsjednici od 1874 do 2004., Zagreb, 2004., 89.

57 V. DugačKi, Ž. KRZnA RIĆ, Hrvatski liječnički zbor od 1874. do 2014., 26.

58 Vijeće je donosilo zakone i reguliralo rad liječnika, rad zdravstvenog osoblja, a sačinjavali su ga vladin predstavnik zadužen za zdravstvo (praliječnik) i najmanje četiri liječnika. (V. Ćosıć, Demografske $i$ javnozdravstvene odrednice razvoja porodništva $i$ primaljstva u Slavonskom Brodu tijekom 19. stoljeća, 20). 
U svojoj liječničkoj praksi uspješno se bavio i veterinarstvom, ${ }^{59}$ a napose okulistikom, te ga je grof Edgar Corberon (1807. - 1861.), ${ }^{60}$ u kontekstu svojih, nažalost bezuspješnih zalaganja bio planirao postaviti kao profesora okulistike na budućem Medicinskom fakultetu Sveučilišta u Zagrebu. ${ }^{61}$ Dr. Vancaš značajno je pridonio razvitku medicinske znanosti. Osim objavljene disertacije De Rabie, 1839. s njemačkog je jezika preveo knjigu o veterini, ${ }^{62}$ koja je do tada imala već 15 izdanja i prijevode na više jezika. ${ }^{63}$ To ima osobit značaj u svjetlu činjenice da je tada bilo malo znanstvene i stručne literature iz medicine na hrvatskom jeziku. ${ }^{64}$ Također je dr. Vancaš i jedan od autora neobjavljenog djela Therapia specialis. ${ }^{65}$

$\mathrm{Na}$ kulturnom planu trajno prisutno u modernoj hrvatskoj povijesti ostaje djelovanje dr. Alekse Vancaša kao jednog od prvih hrvatskih preporoditelja. U njegovoj kući u Opatičkoj 21 u Zagrebu ${ }^{66}$ često su se sastajali ilirski prvaci

59 Veterinarstvo se do 1891. nalazilo u sastavu humane medicine. (Vesna VučeVAC BAJT, Prilog razvoju veterinarstva Hrvatske u XIX. stoljeću, AMHA - Acta medico-historica Adriatica, sv. 5, br. 1, 2007., 55, http://www.amha-journal.com/index.php/AMHA/article/view/232, posjećeno 6. 9. 2019.)

60 Nastanio se u Hrvatskoj, bio pristaša Hrvatskog narodnog preporoda i blizak s banom Jelačićem.

${ }_{61}$ Medicinski fakultet osnovan je 1917. Ovdje treba napomenuti da u Hrvatskoj do 70-ih godina 19. stoljeća nije bilo liječnika specijalista, nego samo liječnika vještih kirurgiji, primaljstvu, okulistici i sl. (V. Ćosıć, Demografske i javnozdravstvene odrednice razvoja porodništva i primaljstva u Slavonskom Brodu tijekom 19. stoljeća, 16).

62 Dr. Aleksa Vancaš, Liečnički vjestnik, br. 10, 1943., 303. Johann Nicolaus RoHLwes, Občinski živinvračitel ali navučanje vsakoga gospodara svoje konje, goveda, ovce, svinje, koze i cucke odkojiti, zderžavati, oveh betege spoznati i vračiti - na horvatski jezik prenešeno po Aleksi Vanczass, Zagreb, 1839., digitalna zbirka HAZU, https://dizbi.hazu.hr/a/?pr=i\&id=290794., posjećeno 8. 9. 2019.

63 L. BRozović, Dr. Aleksa Vancaš, 247.

64 V. Ćosıć, Demografske i javnozdravstvene odrednice razvoja porodnišstva i primaljstva u Slavonskom Brodu tijekom 19. stoljeća, 17.

65 Bene Vancaš, Therapia specialis, rukopis u Sveučilišnoj knjižnici u Zagrebu. (Dr. L. Thaller, Povijest medicine Hrvatske i Slavonije od 1770. - 1850., 113).

66 Kuća Vancaš danas ima status pojedinačnog nepokretnog kulturnog dobra (Z-632), „Današnja jednokatnica u Opatičkoj 21 smještena je na mjestu dviju srednjevjekovnih parcela, koje od 2. pol. 18.st. imaju istog vlasnika. Godine 1798. spominje se kao zidana, a od 1862. nije mijenjala tlocrtne gabarite. Od 1826. kada su vlasnici kuće bili obitelji Stoger - Vancaš - Junković bila je poznata kao sastajalište iliraca..." (Kuća Vancaš, Ministarstvo kulture Republike Hrvatske, Registar kulturnih dobara, https://www.min-kulture.hr/default.aspx?id=6212\&kdId=405475117, posjećeno 18. 9. 2019.). Iz ovih podataka možemo zaključiti da je ovo bila kuća majke dr. Alekse, Terezije Vancaš rođ. Ströger, koju je on naslijedio nakon očeve smrti, a onda je tu nastavila živjeti njegova udovica Josipa. Kako više nisu imali nasljednika, poslije smrti Josipe pl. Vancaš (1910.) kuću je naslijedila sestrična dr. Alekse Marija Junković (Telefonski imenik. Direkcija Zagreb, 1938., https://actacroatica.com/hr/persona/Marija_Junkovic_1//, posjećeno 11. 4. 2019.). Udana je bila za Julia pl. Junkovića od Velikog Tabora (1862. - 1920.), vlastelina Stenjevačkog i velikog 
Ljudevit Gaj, Dimitrije Demeter, Vjekoslav Babukić, Ljudevit Vukotinović, Stanko Vraz, poslije i Petar Preradović, Ivan Trnski, Vatroslav Lisinski, Bogoslav Šulek, Ivan Mažuranić, Ivan Kukuljević, Josip Juraj Strossmayer i drugi. ${ }^{67} \mathrm{Na}$ pročelje kuće Matica je postavila spomen-ploču na kojoj piše: $U$ ovoj kući dr Vancaša i njegove žene Josipe sastajali su se hrvatski preporoditelji. Ovdje je Vatroslav Lisnski skladao prvu hrvatsku operu „Ljubav i zloba“ izvedenu 1846. U povodu 130 - godišnjice hrvatskoga narodnog preporoda ovu spomenploču postavlja u svibnju 1966. Matica hrvatska.

Ilirci su se okupljali i na posjedu obitelji Vancaš u dvoru Kostel kod Pribića, ${ }^{68}$ što su ga braća Janko, Aleksa i Antun Vancaš putem javne dražbe kupili od obitelji Oršić, s kojima su imali višestruke i česte kontakte - dr. Aleksa u ilirskom pokretu, a Antun u pošti. ${ }^{69}$ U popisu imanja Zagrebačke županije iz god. 1854/55.

župana Požeške županije. U njihovu su braku rođene Emilia - Emma udana Lenarčić (1899. 1975.) i Matilda udana Knežević (1905. - 1984.). (Izvor: Natpis na obiteljskom nadgrobnom spomeniku, groblje Mirogoj, rkt odjel, polje 50, razred I, broj 200). Pored ove, Marija je istodobno bila i vlasnica kuće na adresi Stenjevac gornji, koju, za razliku od prve, nalazimo i u Brzoglasnom imeniku Nezavisne Države Hrvatske iz 1942. (https://actacroatica.com/hr/persona/Marija Junkovic/, posjećeno 11.9. 2019.).

67 Nika ŠTrIGA, O stotoj obljetnici smrti Josipe pl. Vancaš (1824. - 1910.), Vijenac, 437, 2. prosinca 2010., digitalno izdanje, http://www.matica.hr/vijenac/437/majka-majcica-ilira-1367/., posjećeno 12.3. 2019.

68 „Uz druge uglednike najčešće su dolazili Ljudevit Vukotinović i Ivan Trnski, a česta je gošća na tim okupljanjima bila i karlovačka književnica Dragojla Jarnević.“ (N. ŠTRIGA, O stotoj obljetnici smrti Josipe pl. Vancaš).

69 U velikom broju posjeda i sjedišta stare hrvatske plemićke obitelji Oršić od 1575. bio je i Kostel. Grof Juraj Oršić Slavetićki (1780. - 1847.), c. kr. komornik, unuk Krste Oršića (1718. - 1782.), velikog župana zagrebačke županije, carsko-kraljevskog komornika, streljačkog pukovnika, političara, kulturnog djelatnika i pristaše ilirskog pokreta te predsjednika Banskog stola, bio je među utemeljiteljima Matice od 1842. (Pregled p.n.gospode pravih utemeljitelja Matice od godišta 1842., Kolo, god. VI, Zagreb, 1848., 12, https://books.googleusercontent.com/books/, posjećeno 15. 9. 2018.). I njegove sestre bile su među utemeljiteljima Matice, a darovatelji su i novčanih priloga za osnutak Narodnog doma. (Vlatka FILIPČıć, Grof Juraj Oršić u preporodnom pokretu, Radovi: Radovi Zavoda za hrvatsku povijest Filozofskog fakulteta sveučilišta u Zagrebu, sv. 29, br. 1, 1997, 163 - 172, https://hrcak.srce.hr/index.php?show=clanak\&id_clanak jezik=76980, posjećeno 11. 3. 2019.). Obitelj Oršić blisko je vezana i za povijest hrvatske pošte. Grof Ivan Nepomuk Oršić, mlađi brat Jurja Oršića, sve do svoje smrti 1817. bio je upravitelj pošte („poštanski majstor“) u Zagrebu, u vlastitoj kući u Poštanskoj ulici (danas Opatička br. 12 i 14). Kako je to bio dobar izvor prihoda, i njegov sin, grof Ernest Oršić, od 1820. bio je upravitelj pošte u Zagrebu, a potom i grofica Julijana Oršić, posljednja prije reorganizacije poštanskog prometa 1848. (Željka Kolveshi, Upravitelji pošte u Zagrebu iz obitelji grofova Oršić Slavetičkih, u: Grofovi Oršić u Hrvatskom zagorju, ur. Vlatka Filipčić Maligec, Gornja Stubica, 1996., 35 - 40, http://www.mgz.hr/UserFiles/file/Orsic-MHZ-1996.pdf., posjećeno 12. 3. 2019.) 
braća Vancaš upisani su kao vlasnici imanja Kostel s 11,5/8 selišta i 26 selišnih obitelji, te posjeda, također u Kostelu, o kojima nisu sačuvani podatci. ${ }^{70}$

Na imanju Kostel imali su i vinograde, o čemu svjedoče i nagrade koje su na izložbama poljoprivrednih proizvoda dobivali dr. Aleksa, a nakon njegove smrti, supruga Josipa i bratić Josip Vancaš. ${ }^{71}$ Dvor Kostel naslijedila je kći Josipove sestre Eme, Josipa Kukuljević-Sakcinski rođ. Thierry (1876. - 26. prosinca 1964.), udana za Franu pl. Kukuljević-Sakcinskog (1870. - 1954.). ${ }^{72}$

Na poticaj grofa Janka Draškovića, preporoditelji su 22. kolovoza 1838. u Zagrebu osnovali ilirsku Čitaonicu. Pod okriljem Čitaonice, na redovitom saboru 10. veljače 1842. utemeljena je Matica ilirska kao njezina glavnica i odlučeno da se uputi javni poziv "gospodi domorodcima“ za uplatu 50 for. srebra ili kroz petjednakih godišnjih obroka čime će postati utemeljitelji Matice ilirske. Za predsjednika odbora Matice pod okriljem Čitaonice izabran je dr. Ljudevit Gaj, a dr. Aleksa Vancaš za blagajnika, što će ostati do osamostaljenja Matice hrvatske u lipnju $1850 .^{73}$

70 Štefanija Popović, Popis imanja Zagrebačke županije u doba ukidanja feudalnih odnosa, Radovi: Radovi Zavoda za hrvatsku povijest Filozofskog fakulteta sveućilišta u Zagrebu, sv. 28. br. 1, Zagreb, 1995., 286, https://hrcak.srce.hr/50246., posjećeno 11.9. 2018. Na ovome popisu pod red. br. 342. je Župa Sv. Ana (Podturan) sa 7,1/8 selišta i 17 selišnih obitelji, uz navođenje da je župnik Janko Vancaš. Nakon ukidanja feudalnih odnosa u Hrvatskoj u srpnju 1848., kmet je postao vlasnik selišne (urbarijalne) zemlje, pa su na osnovu odluke c. i kr. Komisije za razterećenje zemaljah, bivši feudalni vlasnici imanja dobivali odštetnu glavnicu i rentu. U Oglasu poradi doznačenja zemljištnorazteretnih odštetnih glavnica, braća Vancaš ovlaštenici su za naknadu 9,1/8 nekadašnjih selišta Kostela. Prema odštetnoj presudi br. 1883 od 19. kolovoza 1856. iznos odštetne glavnice bio je 3.075 fr. i 33 kr. (Carsko-kraljevske službene narodne novine, br. 215, 18. 9. 1856., 726).

71 Nagrada za vinograd iz zaklade Mirka Haraminčića Gospodarskom društvu za godinu 1863. podijeljena je dr. Aleksi Vancašu u Krašićkom kotaru. (G.I. Narodno gospodarstvo, Domobran, br. 178, 16. 12. 1864., 4); Na Obrtnoj i gospodarskoj izložbi u Trstu 1882. u kategoriji za likere i vina dr. Aleksi Vancašu iz Zagreba dodijeljena je zlatna kolajna. (Nagrade na tršćanskoj izložbi, Narodne novine, br. 268, 22. 11. 1882., 5). Diploma za ocat Josipi Vancaš, Zagreb na Gospodarsko - šumarskoj jubilarnoj izložbi hrvatsko - slavonskoggospodarskog društva u povodu 50. god djelovanja ovog Društva održanoj u Zagrebu 15. kolovoza 1891. (Izložbena porota za hrvatska, slavonska, dalmatinska i istarska vina, pivo i rakiju i t. d., Narodne novine, br. 259, 11. 11. 1891., 4). Na povremenoj izložbi voća, grožđa i vrtnih proizvoda održanoj u okviru ove izložbe, među izlagateljima je bio i „Josip Vancaš u Kostelu“. (S izložbe, Pravi prijatelj naroda, br. 25, 3. 10. 1891., 2).

72 Josipin suprug Frano je kao vlastelin u Krašiću naveden u Ljetopisu i imeniku književnog društva SvetogJeronima iz 1906., 86 (https://actacroatica.com/hr/persona/Fran_Kukuljevic_1/, posjećeno 21. 9. 2019.). U Imeniku dostojanstvenika, činovnika i javnih službenika Kraljevina Hrvatske $i$ Slavonije (Zagreb, 1917., https://actacroatica.com/hr/persona/Kukuljevic_Sakcinski_Pl_Fran_1/, posjećeno 16. 9. 2019.) je među članovima Nadzornog odbora Hr.-slav. gospodarskog družtva upisan kao „vlastelin i kr. vel. župan u m. u Kostelu“. Također je naveden i kao potpredsjednik zadruge ovoga Društva u Krašiću.

73 Tade Smičílas, Franjo Marković, Spomen-knjiga Matice hrvatske: Matica hrvatska od godine 1842. do godine 1892., Zagreb, 1892., digitalni preslik izvornika, http://www.matica.hr/knjige/ 
U govoru na glavnoj skupštini 24. ožujka $1912 .{ }^{74} \mathrm{dr}$. Oton Kučera, predsjednik Matice hrvatske, i nakon sedam desetljeća s velikom zahvalnošću spominje članove prvog odbora Čitaonice, njezine utemeljitelje i darovatelje. Istaknuo je da „prvih osam godina do godine 1850. Matica raste kao nježna biljka pod okriljem Čitaonice, pak je narodu hrvatskomu na području nauke i književnosti sve, što on ima: i akademija i knjižar - nakladnik“. A to je upravo razdoblje djelovanja dr. Vancaša u njezinu Odboru.

Narodna Čitaonica bila je „prava majka rodilica narodnoga teatra, gospodarskoga društva, narodnoga muzeja, Matice ilirske i Narodnoga Doma“. Za sve njih vezan je rad dr. Alekse. Bio je, kao i njegov brat, župnik Janko, utemeljitelj Matice. ${ }^{75}$ Također je bio u ravnateljstvu Narodnog doma, ${ }^{76}$ a potom i njegov predsjednik. ${ }^{77}$ Priložnik je za numizmatičku zbirku Narodnog zemaljskog muzeja, ${ }^{78}$ čijoj je knjižnici darovao preko stotinu svezaka nekoliko liječničkih časopisa (1869.). ${ }^{79}$ Bio je član i potpredsjednik Hrvatsko-slavonskog gospodarskog društva u Zagrebu, osnovanog 3. veljače 1841. U funkciji zemljoradničke komore, za cilj je imalo unapređenje poljoprivredne tehnike, a „kao sredstva bila su predviđena stručna predavanja, širenje knjiga i novina, osnivanje uzornih objekata, voćnjaka, loznih rasadnjaka, spremanje izložaba, davanje nagrada itd.“80

matica-hrvatska-od-godine-1842-do-godine-1892-1072/\#b4., posjećeno 16. 3. 2019. Ova funkcija blagajnika bila je važna i zbog toga što su iz Matičine glavnice, uz ustanovljene kamate, davani novčani zajmovi. Više u: Nepoznati zapisnici Matice ilirske, prir. Stjepan Laljak, Vijenac, 286, 17. 2. 2005., http://www.matica.hr/vijenac/286/za-jedinstveni-pravopis-9355/., posjećeno 16. 10. 2019. U tom se razdoblju sjedište Čitaonice i Matice više puta mijenjalo, a kako je to bilo i financijski zahtjevno, dr. Vancaš je kao blagajnik imao značajnu ulogu.

74 O „Matici Hrvatskoj“, Jutarnji list, br. 24, 27. 3. 1912., 1 - 3.

75 Nakon što su kao „obvezani utemeljitelji“ kroz pet godina (1842. - 1846.) ispunili glavnicu od 50 for. srebra, smatrani su pravim utemeljiteljima, pa su u Pregledu p. n. gospode pravih utemeljitelja Matice od godišta 1842., braća Janko i dr. Aleksa Vancaš navedeni među 148 pravih utemeljitelja u godini 1845. (Račun od Matice horvatsko-slavonske načinjen koncem godišta 1846., Kolo, god. VI, Zagreb, 1848., 14, https://books.googleusercontent.com/books/, posjećeno 15. 9. 2018.).

76 Četverta obća skupština gg. upravljujućih akcionarah Narodnoga doma 23. rujna. Novine dalmatinsko - hervatsko - slavonske, br. 16. 10. 1847., 330.

77 Glavna skupština družtva narodnoga doma, Domobran, br. 64, 19. 3. 1866., 4.

78 D. R. Dalji priložnici na sabirke koje se nahode kod družtva gospodarskoga hèrvatsko slavonskoga u narodnom domu za mineralošku i numizmatičnu zbirku (s 1 bakrenim i 2 srebrena novčića). Novine dalmatinsko - hervatsko - slavonske, br. 80, 6. 10.1847., 318; D. R. Museum, Narodne novine, br. 166, 15. 10. 1849., 554 .

79 Tihana Luetić, Darovi i davatelji Arheološkom odjelu Narodnog zemaljskog muzeja u Zagrebu od 1868. do 1875. godine, Vjesnik Arheološkog muzeja u Zagrebu, sv. 34, br. 1, 2001., 227, https://hrcak. srce.hr/25292, posjećeno 22.6.2019.

80 Hrvatsko-slavonsko gospodarsko društvo (1841. - 1929.), HR-HDA/S - 8345, Nacionalni arbivski informacijski sustav, http://arhinet.arhiv.hr/details.aspx?ItemId=3_8345., posjećeno 20. 3. 2019. 
Prema novim Pravilima od 7. studenog 1859., svrha je ovoga Društva „napredak i savršenstvo poljodjelstva, šumarstva i gospodarskog obrta, rasprostiranje znanja o zemlji i istraživanje u gospodarstvu“" ${ }^{\circ 1}$

Trajni spomen na kulturnom planu zavrijedio je i kao član nadzornog odbora Narodnog kazališta, ${ }^{82}$ utemeljitelj zagrebačkog Glazbenog konzervatorija, ${ }^{83}$ namjesnik ravnatelja i načelnik gospodarskog odbora Narodnog zemaljskog glasbenog zavoda u Zagrebu. ${ }^{84}$ Bio je načelnik gospodarskog odbora zagrebačkog Družtva prijatelja muzike, osnovanog 1827. sa svrhom „razprostranjenja i promicanja muzike u domovini“" ${ }^{85}$ Nalazimo ga i na popisu darovatelja priloga za potporu muzike Narodne straže ${ }^{86}$ i Srbskog pjevačkog družtva u Zagrebu, ${ }^{87}$ kao i da je sa suprugom Josipom crkvi sv. Marka u Zagrebu darovao oslikani prozor. ${ }^{88}$

Od 1851. je kao gradski zastupnik kroz tri desetljeća pridonosio razvitku Zagreba, ${ }^{89}$ kao što će i Josip Vancaš činiti u Sarajevu. Osobito je zaslužan za uređenje bolnice u Zagrebu. Njegovo zalaganje kao pročelnika gospodarskog odjela, člana, a onda i predsjednika Vodovodnog odbora, formiranog 1861. sa zadaćom da se grad opskrbi pitkom vodom iz gorskih krajeva, ${ }^{90}$ rezultiralo je prvim suvremenim zagrebačkim vodovodom, koji je svečano otvoren 7 . srpnja $1878 .^{91}$

Za zasluge oko podizanja gradske bolnice u Požegi Gradsko zastupstvo izabralo ga je počasnim građaninom ovoga grada. ${ }^{92}$ Bio je i počasni građanin Varaždina (1879.) i Karlovca. ${ }^{93}$ Kao prvi fizik zagrebačke varmeđe 1845.

81 Hrvatsko-slavonsko gospodarsko društvo, (1841. - 1929.), HR-HDA/S - 8345.

82 Zapisnik sjednice upravnog i nadz odbora održane u Zagrebu 4. 12. 1858. Carsko - kr. službene narodne novine, br. 282, 19. 12. 1858., 767.

83 Narodne novine, br. 52, 4. 3. 1852., 1. U skladu s pravilima Društva o visini utemeljiteljne glavnice, položio je 100 for. u srebru.

${ }^{84}$ Zapisnici glavne godišnje skupštine narodnoga zemaljskoga glasbenoga zavoda u Zagrebu, Domobran, br. 52, 5. 3. 1866, 4; Narodne novine, br. 17, 21. 1. 1867., 3; Narodne novine, br. 35, 12. 2. 1868, 3; Narodne novine, br. 156, 12. 7. 1870., 3.

85 Poziv za stanovničtvo grada Zagreba, Carsko - kr. službene narodne novine, br. 107, 8. 5. 1860, 287 - 288.

86 Glasnik, Slavenski jug (Zagreb), br. 6, 13. 1. 1849., 24. Godišnji prilog bio je 6 for.

87 Izvješće, Narodne novine, br. 111, 16. 5. 1883., 4.

88 Crkva sv. Marka u Zagrebu. Narodne novine, br. 113, 17. 5. 1882., 3, „za uspomenu velikodušnih darovateljah" na prozoru su upisana njihova imena.

89 „Za to vrijeme bio je 'duša magistrata'“ (L. Brozović, Dr. Aleksa Vancaš, 247).

90 Zlatko Jurić, Vodovod u Zagrebu: od ideje do ostvarenja 1861. do 1878., Život umjetnosti, br. 60, 1998., 49 - 66, https://www.ipu.hr/content/zivot-umjetnosti/ZU_60-1998_048-066_Juric.pdf., posjećeno 10.5. 2019.

91 Ime dr. Vancaša je na Svečanoj povelji o osnutku zagrebačkog vodovoda, 1878. (Arhivski fond: HR-DAZG-10 Gradsko poglavarstvo Zagreb, Gradska poduzeća, GP 1/3, http://daz.hr/svecanapovelja-o-osnutku-zagrebackog-vodovoda-1878-hr-dazg-10-gradsko-poglavarstvozagreb-gradska-poduzeca-gp-13/, posjećeno 22. 3. 2019.).

92 L. Brozović, Dr. Aleksa Vancaš, 247.

93 Dr. Aleksa Vancaš, Narodne novine, br. 148, 28. 6. 1884., 4. 
imenovan je ,za prisednika sudbenoga stola varmedje varaždinske“, ${ }^{44}$ a 1847. za prisednika Križevaca (Veliko spravište). ${ }^{95}$

Kao strjeljački savjetnik dr. Vancaš bio je i u ravnateljstvu Građanskog streljačkog društva u Zagrebu, ${ }^{96}$ koje je po uzoru na srednjoeuropske zemlje 1786. osnovao grof Juraj Oršić i na svojem imanju podigao Streljanu s dvoranom. Osim natjecanja, ovdje su organizirane glazbene akademije, zabave s plesom te koncertne i recitatorske večeri rodoljubne poezije. Kako su među istaknutim članovima bili i hrvatski preporoditelji, ${ }^{97}$ ova su okupljanja imala širi društveni, kulturni i politički značaj.

Bio je član i Družtva čovječnosti, prvog dobrotvornog društva u Zagrebu, ${ }^{98}$ utemeljenog 1846. za sa svrhom da „podupire siromaštvo ne samo novcem gotovim, već i načinom onim koji je najvaljaniji da po razmierju obstojateljah bude uklonjena nevolja“. ${ }^{99}$ Ovu obiteljsku crtu solidarnosti s potrebitima iskazao je i kao darovatelj potpore za učiteljsku siročad. ${ }^{100}$

Dr. Vancaš je svojim angažiranjem pridonio i razvitku hrvatskog gospodarstva. ${ }^{101}$ Bio je dioničar i član upravnog odbora ${ }^{102}$ Prve hrvatske štedionice

94 Iz Varaždina, Novine horvatsko - slavonsko-dalmatinske, br. 103, 24. 12. 1845., 1.

95 Iz Križevcah dne 20. svibnja (Vel. spravište). Novine dalmatinsko - hervatsko-slavonske, br. 41, 22. 5. 1847., 162. Termin „spravište“ korišten je za zasjedanje skupštine Križevačke županije. (Hrvatska enciklopedija, mrežno izdanje, Leksikografski zavod Miroslav Krleža, http://www.enciklopedija. $\mathrm{hr} /$ natuknica.aspx id= 57524 , posjećeno 21.10 .2019 .).

96220 godina streljaštva u Zagrebu. Slike iz streljačke prošlosti, ur. Kruno Sabolić, Zagreb, 2006. 30, http://www.zsa.hr/images/stories/monografija/monografija.pdf, posjećeno 12. 12. 2018. Ravnateljstvo Društva, čiji su članovi bili pripadnici društvene elite, uključujući i žene, činili su nadmeštar, prvi ravnatelj i strjeljački savjetnici.

97 Grof Janko Drašković, dr. Ljudevit Gaj, dr. Dimitrije Demeter, Dragutin Rakovac, Ivan Kukuljević Sakcinski, ban Josip Šokčević, biskup Josip Juraj Strossmayer, ban Ivan Mažuranić. (220 godina streljaštva u Zagrebu, 29 - 30).

98 Imenik prautemeljiteljah, utemeljiteljah i članovah zagrebačkoga Družtva čovječnosti, Zagreb, 1868. , 11, https://digitalnezbirke.kgz.hr/ ?object=view\&id=18341., posjećeno 4. 9. 2019.

99 Pravila obstojećega od godine 1846. sada preustrojenoga zagrebačkoga Družtva čovječnosti: odobrena razpisom visoga c. kr. miestoderštva od 1. prosinca 1856, br. 22552-41681875, http://kgzdzb.arhivpro. $\mathrm{hr} /$ ?kdoc=301004432., posjećeno 24. 10. 2019.

100 Prema Izkazu članovah, plativši svoje prineske kao utemeljitelji, redovoti članovi, ili podupiratelji Zadruge učiteljskoga družtva za podporu učiteljske siročadi, dr. Vancaš je priložio 70 for. (Narodne novine, br. 80, 7.4. 1866, 3.). Iste je godine i njegova supruga Josipa navedena kao članica Centralnog gospojinskog odbora za svrhu „učiteljske zadruge”, koja je podupirala i odgoj učiteljske siročadi. Narodne novine, br. 86, 14. 4. 1866., 2.

101 Glavno zdravstveno povjerenstvo Zagreba je, temeljem proglasa od 27. rujna 1866., odredilo zemaljskog savjetnika dr. Vancaša za člana odbora u prvom od šest gradskih kotara u svrhu preduhitravanja kolere. Odbore su činili predsjednici iz reda svećenika te liječnici i ranarnici. Oglas, Narodne novine, br. 225, 1. 10. 1866., 3.

102 Obći zagrebački Kolendar za godinu 1847., ur. Slavoljub Vrbančić, Zagreb, 1847., 220, https://books. google.hr/books?id=fedYAAAAcAAJ, posjećeno 21. 10. 2018. 
u Zagrebu ${ }^{103}$ koja je s radom počela 1. prosinca 1846. Od $1865 .{ }^{104}$ do smrti 1884 . bio je i njezin predsjednik. ${ }^{105} \mathrm{Na}$ sjednici Glavne skupštine 29. travnja 1884., kojoj je predsjedavao, za „revno i uspješno djelovanje“ u zapisnik mu je iskazano priznanje. ${ }^{106}$ Također je bio i suosnivač i izabrani predsjednik nacionalne gospodarske institucije Osiguravajuće društvo Croatia, utemeljene 4. lipnja 1884. ${ }^{107}$

Radno aktivan ostao je do samoga kraja. „Bijaše kroz cieli svoj život vrlo radina pak i vrlo uvažena osoba što dokazuju njegova tolika odlikovanja“, ${ }^{108}$ među njima i odličje viteza reda Franje Josipa (1890. dodijeljeno i Josipu Vancašu ${ }^{109}$ ).

Preminuo je 28. lipnja 1884. u dvoru Kostel, ${ }^{110}$ a pokopan na groblju crkve Blažene Djevice Marije u Dolu, ${ }^{111}$ jer je želio počivati blizu svojega brata, ${ }^{112}$ što je još jedna potvrda jakih i neugaslih obiteljskih veza. Također, „u tom krasnom

103 Od osnutka do 1861. nosila je naziv Pàrva hàrvatska štedionica u Zagrebu. Osnivači su bili istaknuti ilirci, među kojima LJ. Gaj, D. Demetar, A. Mažuranić, barun A. Vranyczany i dr. Početna dionička glavnica bila je 40.000 srebrenih forinti u 400 dionica po 100 forinti (Arhivski fond HR-HDA 570, http://arhinet.arhiv.hr/details.aspx?ItemId=1_4488, posjećeno 22.4.2019.). Upravu su, osim predsjednika i potpredsjednika, činila i 24 člana odbora, od kojih su njih 14, među kojima idr. Vancaš, bili istodobno i članovi Hàrvatsko-slavonskog gospodskog društva, što je kao počast stavljano iza imena. Iako sa skromnim početnim kapitalom, ovaj prvi domaći novčani zavod u Hrvatskoj je u 20. stoljeću postao najjača financijska institucija u zemlji. Vrijedno je ovdje napomenuti da je monumentalna Palača Prve hrvatske štedionice sagrađena 1898. - 1900. po projektu arhitekta Josipa pl. Vancaša, čiji je sin Alfred, nakon preseljenja obitelji u Zagreb (1921.), bio njezin činovnik. (Autobiografska zabiljeska; Telefonski imenik. Direkcija Zagreb, 1938., pretisak povijesnog izvora, Acta Croatica, , https://actacroatica.com/hr/persona/Alfred_Vancas_2/, posjećeno 14. 5. 2019.).

104 Zagreb, Domobran, br. 46, 25. 2. 1865., 2.

105 Dr. Aleksa Vancaš, Liečnički vjestnik, br. 10, 1943., 305.

106 Glavna skupština prve hrvatske štedionice, Narodne novine, br. 100, 30. 4. 1884., 5; „Poglavito njegovim nastojanjem sagradila je prva hrvatska štedionica veleliepu sgradu“. Dr. Aleksa Vancaš, Narodne novine, br. 148, 28. 6. 1884., 4.

107 Dr. Aleksa Vancaš, Liečnički vjestnik, br. 10, 1943., 305.

108 † Dr. Aleksa Vancaš, Narodne novine, br. 148, 28. 6. 1884., 4.

109 Čestitka, Vrhbosna, br. 4, 15. 2. 1890., 75. Ovo visoko carevo odlikovanje arhitekt Vancaš dobio je za svoje prve projekte - sarajevsku Katedralu, (1889.) i palaču Zemaljske vlade (1885.), koji će ostati među njegovim najznamenitijim objektima u ukupnom stvaralačkom opusu. Orden je utemeljen patentom cara Franje Josipa I. od 2. prosinca 1849., a podjeljivao se „austriskom državljaninu za privrženost caru i domovini i zaslugama stečenim za opće dobro u poljodjelstvu, obrtu, trgovini, umjetnost ili znanosti, čime je stekao zahvalnost domovine i javno priznanje“. Cesarski patent od 25. prosinca 1850. Reichsgesetzblatt 1849 - 1918 (kroatisch), 99 - 104, http://alex.onb.ac.at/ cgicontent $/$ alex aid $=r$ sk\&datum $=1851 \&$ page $=967 \&$ size $=45$, posjećeno 11. 4. 2019.

110 Pogreb dr. Alekse Vancaša, Narodne novine, br. 150, 1.7. 1884., 4.

111 Sadašnja crkva sv. Ane nastala je na kapeli Blažene Djevice Marije, uz koju je podignut zvonik. Obnovljena je nakon znatnih oštećenja u potresima 1868. i 1877. (Crkva svete Ane, Gorica Svetojanska, http://www.jastrebarsko.hr/jastrebarsko/kuturna_bastina/sakralni-objekti/, posjećeno 16. 9. 2019.).

112 † Dr. Aleksa Vancaš, Narodne novine, br. 148, 28. 6. 1884., 4. 
predjelu želio je pokojnik počivati u blizini svoga posjeda, koji je velikom ljubavi uzorno gajio“.113

Prema obrascu sklapanja braka s uglednim obiteljima, kojima je pospješivan društveni status i karijera, dr. Vanacaš se 1833. ženi „iz kuće dra Daubacha“.114 Njegova supruga Ivana Nepomuka (Minka) rođ. Daubachy ${ }^{115}$ bila je kći dr. Ivana Nepomuka Daubachyja de Dolje (1766. - 1843.), koji je bio među osnivačima ilirske Čitaonice, ${ }^{116}$ kao i dr. Aleksa. Dr. Daubachy bio je redoviti gradski fizik (1. prosinca 1809. - 1. kolovoza 1835.), a protomedikus Kraljevine Hrvatske od 1835. do smrti. ${ }^{117}$ Kako je i dr. Vancaš bio gradski fizik, a onda i protomedik, njihovi susreti i suradnja morali su biti česti, što je moglo utjecati i na sklapanje ovoga braka.

Međutim, supruga mu je preminula već $1836 .{ }^{118}$ Druga supruga bila je Josipa rođ. Andrassy (Gračac, 26. travnja 1821. - Zagreb, 18. ožujka 1910.). Nakon što je rano ostala bez roditelja, skrb je preuzeo ujak, kanonik Mihić u Zagrebu. Prigrlila je ideje iliraca, pomagala njihove rodoljubne i dobrotvorne akcije, podupirala ilirsku Čitaonicu, Maticu ilirsku, Hrvatsko-slavonsko gospodarsko društvo, a bila je pretplaćena i za dvoranu Streljačkog društva. ${ }^{119}$ „Majčica Ilira“, kako su je zvali, pomagala je sirotinju i siromašne đake, ${ }^{120}$ glađu stradale u Hrvatskoj i Slavoniji ${ }^{121}$ i sa suprugom skrbila u bolesti Stanka Vraza (1810. -1851.), tadašnjeg

113 Pogreb dr. Alekse Vancaša, Narodne novine, br. 150, 1. 7. 1884., 4. U članku je navedeno da su na sprovodu „velečasnoga i mnogozaslužnoga rodoljuba dra. Alekse Vancaša“, osim obitelji - supruge, brata Antuna pl. Vancaša, tada ravnatelja pošta i kr. savjetnika, unuka, nećaka i nećakinja - bili mnogi osobni prijatelji, deputacije iz grada Zagreba, magistrata i zastupstva iz grada Karlovca, Općina Jaske i Krašića, predstavnici Matice hrvatske, Prve hrvatske štedionice, Zbora hrvatskih liječnika, Trgovačko-obrtničke komore (Janko Grahor) te brojni pojedinci i sva vlastela iz okolice. Uz koral od devet osoba i zbor pjevača „Kolo“, pogreb je vodio kanonik Gašparić uz asistenciju osam župnika (iz Sv. Jane, Krašića, Pribića, Jaske itd.). Uprava Prve hrvatske štedionice osigurala je poseban vlak Zagreb - Jaska. Zadušnice su najavljene za 3. srpnja u crkvi sv. Marka u Zagrebu. Javnu zahvalu svim sudionicima sprovoda iz Kostela je 1. srpnja uputila obitelj: Josipa Vancaš, Anton pl. Vancaš, brat i Nikola pl. Suzani, unuk (Javna zahvala, Narodne novine, br. 152, 3. 7. 1884., 4).

114 Dr. Aleksa Vancaš, Narodne novine, br. 148, 28. 6. 1884., 4.

115 Theodor de Canziani Jakšıć, Protomedicus Kraljevine Hrvatske Dr. Ivan Christoph Nepomuk Daubachy de Dolje u Spomeničkoj knjižnici i zbirci Mažuranić - Brlić - Ružić, AMHA - Acta medico-historica Adriatica, sv. 8, br. 2, 2010., 214, https://hrcak.srce.hr/63532, posjećeno 11. 6. 2019.

116 B. BeliczA, D. ORlić, Hrvatski liječnički zbor: predsjednici od 1874. do 2004., 89.

117 Podatci iz vlastoručne autobiografske zabilješke datirane 15. siječnja 1840. (T. de CANZIANI JAKŠıĆ, Protomedicus kraljevine Hrvatske dr. Ivan Christoph Nepomuk Daubach - Daubachy de Dolje, 211 - 220)

118 L. Brozović, Dr. Aleksa Vancaš, 247.

119 Ples mlade gospode, Narodne novine, br. 8, 11. 1. 1883., 2.

120 Više u: Antonija KAssowitz-Cvijıć, Josipa Vancaš, nazvana „Majčica Ilira“, Hrvatsko kolo, knj. 10, Zagreb, 1929., 41 - 85.

121 Izkaz XVII. Narodne novine, br. 64, 18. 3. 1872., 3. Prilog od 5 fr. 
tajnika Matice ilirske, ${ }^{122}$ i Vatroslava Lisinskog (1819. - 1854.). ${ }^{123}$ Bila je i članica Centralnog gospojinskog odbora za svrhu Učiteljske zadruge, koja je podupirala odgoj učiteljske siročadi. ${ }^{124}$ Hrvatska povijest bilježi je kao pionirku „ženskog osvješćivanja, okupljanja i učenja o vlastitu narodu“ ${ }^{125}$ Imala je istaknutu ulogu u Domorodnom gospojinskom društvu za odgoj sitne djece u narodnom jeziku i domorodnom duhu, koji je 1842. utemeljila Ivana pl. Čačković, s osnovnim ciljem buđenja narodne svijesti u žena te brige i odgoja djece u nacionalnom duhu. ${ }^{126}$

Nažalost, djeca, pa i unuk dr. Alekse i Josipe Vancaš nisu dugo poživjeli. Sin Juraj Josip - Jurica, rođen 1844., umro je od šarlaha navršivši jedva četiri godine. Kći Otilija, udana Suzani, preminula je 1861. u svojoj 21. godini. Njezina kći Alissa umrla je već u drugoj godini života, a sin Nikola - Nikica, rođen 1861., umire od trbušnog tifusa u siječnju 1885. godine. ${ }^{127}$

Premda je ostala sama, bez supruga, djece i unučadi, ${ }^{128}$ Josipa Vancaš nije posustajala u svojim dobrim djelima. Bila je i utemeljitelj Družtva za prehranu siromašne školske mladeži u Zagrebu, s izdašnim prilogom od 50 for. ${ }^{129} \mathrm{Na}$ poziv dr. Izidora Kršnjavog, predstojnika Odjela za bogoštovlje i nastavu u Zemaljskoj vladi, bila je članica Gospojinske ankete glede preustrojstva odnosno nadopunjenja viših djevojačkih školah. ${ }^{130}$ Izdašno je podupirala čitaonicu u Krašiću. ${ }^{131} \mathrm{U}$ popisu mecena i dobrotvora Matice hrvatske nalazimo njezin legat od 2.000 kruna u god. 1909. i dar od 50 for. za podmirenje troškova prijenosa posmrtnih ostataka Janka Draškovića u Zagreb. ${ }^{132}$ Oporučno je za siromahe Zagreba ostavila $6.000 \mathrm{~K}$, Matici hrvatskoj $2.000 \mathrm{~K}$, po $1.000 \mathrm{~K}$ crkvama u Pribiću i Dolu, gdje je sahranjena u obiteljskoj grobnici. ${ }^{133} \mathrm{U}$ znak sjećanja i zahvalnosti

122 Nazivali su je „mamica Stanka Vraza“. Plemeniti dar, Banovac, br. 14, 3. 4. 1910., 3.

123 Matica hrvatska 1842 - 1997., ur. Josip Bratulić, Zagreb, 2008., Biblioteka Elektronička izdanja, http://www.matica.hr/knjige/997/, posjećeno 28.4. 2019.

124 U Zagrebu, 14. travnja. Narodne novine, br. 86, 14. 4. 1866., 2.

125 N. ŠTrigA, O stotoj obljetnici smrti Josipe pl. Vancaš.

126 Klementina BATINA, Aspekti ženskog autorstva: komparativna analiza etnološke i folklorističke grade $H A Z U$, doktorski rad, Filozofski fakultet Sveučilišta u Zagrebu, Zagreb, 2015., 52. http://darhiv.ffzg.unizg.hr/id/eprint/5778/1/K.Batina_PhD.pdf, posjećeno 14. 5. 2019.

127 N. ŠTrigA, O stotoj obljetnici smrti Josipe pl. Vancaš.

128 Nastavila je živjeti u Opatičkoj 21, gdje je kao „posjednica - Besitzerin“ navedena u Prvom adresaru grada Zagreba iz 1902., https://actacroatica.com/hr/persona/Josipa_Vancas/, posjećeno 10. 10. 2018.

129 Novi izkaz u zakladu. Narodne novine, br. 12, 16. 1. 1892., 3.

130 Gospojinske ankete glede preustrojstva odnosno nadopunjenja viših djevojačkih školah, Narodne novine, br. 26, 3. 2. 1892., 2.

131 Krašić, Svjetlo (Karlovac), br. 36, 8. 9. 1901., 2.

132 Josip BRLEKović, Mecene i dobrotvori Matice hrvatske, Kolo, br. 3, 2017., http://www.matica.hr/ kolo/534/mecene-i-dobrotvori-matice-hrvatske-27577/, posjećeno 14. 9. 2018.

133 Plemeniti dar, Sloga (Karlovac), br. 14, 3. 4. 1910., 3. 
za njezinu darežljivost i dobročinstva Zaklada „Zamah“ iz Zagreba je 2011. utemeljila nagradu „Josipa Vancaš” kojom se promiče ženska filantropija. ${ }^{134}$

\section{ALEKSA VIKTOR PL. VANCAŠ - POŽEŠKI (Požun/Bratislava, 1849. - Zagreb, 14. travnja 1937.) $)^{135}$}

Josipov stariji brat Aleksa (Alexa ${ }^{136}$ ) Viktor pl. Vancaš Požeški bio je pravnik, kao i njegov otac. $U$ onodobnom tisku nalazimo da je najprije bio kotarski pristav kod kotarskog suda u Karlovcu, potom sudac u Čabarskom kotaru, ${ }^{137}$ vijećnički tajnik kod Sudbenog stola u Zagrebu, ${ }^{138}$ kotarski sudac u Pisarovini, ${ }^{139}$ predsjednik kr. sudbenog stola u Petrinji od rujna $1892 .{ }^{140}$ do siječnja 1902., kada je imenovan kr. državnim nadodvjetnikom u Zagrebu. ${ }^{141}$ Bio je i član Pravničkog družtva u Zagrebu. ${ }^{142}$

Među utemeljiteljima je Družtva za potporu učiteljskih pripravnika ${ }^{143}$ i darovateljima Dobrovoljnog vatrogasnog družtva u Petrinji. ${ }^{144}$ Bio je strastveni lovac $^{145}$ i redoviti član Hrvatskog planinarskog društva u Zagrebu. ${ }^{146}$ Društveno aktivna bila je i njegova supruga Ema, koju u tisku nalazimo kao predsjednicu Pododbora za osnutak Jelisavine zaklade u Petrinji. ${ }^{147}$

134 Više na: http://dobrotvorka.zamah.hr/.

135 Podatak o datumu smrti na web stranici Gradska groblja, https://www.gradskagroblja.hr/default. aspx?id=382, posjećeno 11.3 .2019$.

136 Ime Alexa upisano je na nadgrobnom spomeniku (Mirogoj, rkt odjel, polje 9, razred II/I, broj 36).

137 Priposlano, Primorac, br. 14, 17. veljače 1875., 3.

138 Imenovani, Sriemski Hrvat (Vukovar), br. 89, 7. 11. 1883., 3.

139 Imenovanja i premještaji u sudstvu, Sriemski Hrvat (Vukovar), br . 79, 1. 10. 1884., 4.

140 Promjene u predsjedničtvu sudbenog stola, Banovac, br. 39 , 24. rujna 1892., 3.

141 Vjestnik, Banovac, br. 5, 25. siječnja 1902., 2.

142 Pravničko družtvo u Zagrebu, Narodne novine, br. 43, 23. 2. 1892., 3. Društvo je osnovano 28. veljače 1875 .

143 Članovi družtva, Banovac, br. 7, 16. 2. 1895., 2; Banovac, br. 20, 11. 5. 1901., 2.

144 Javne zahvale, Banovac, br. 7, , 8. veljače 1902., 4.

145 Priposlano, Primorac, br. 14, 17. veljače 1875., 3.

146 Hrvatsko planinarsko društvo u Zagrebu godine 1904., Hrvatski planinar, br. 5 i 6., 1904., 25, https://www.hps.hr/hp-arhiva/190405.pdf, posjećeno 3. 3. 2019. Društvo je osnovano 1874. i najstarije je među takvim slavenskim društvima, a samo godinu dana mlađe od sličnog njemačkoaustrijskog društva. Članovi su većinom bili iz redova zagrebačke inteligencije i građanstva. (Hrvatska planinarska zložba, Dom i svijet, br. 4., 15. 2. 1922., 61). U vrijeme rata (1914. - 1917.) rad društva bio je obustavljen. (Hrvatsko planinarsko društvo, Banovac, br. 40, 29. 9. 1917., 3).

147 Imenovana je na sjednici 29. travnja 1899. i kao supruga predsjednika kr. sudbenog stola u Petrinji, Alekse Vancaša, preuzela je prikupljanje kod sudbene struke. Jelisavina zaklada, Banovac, br. $20,13$. 5. 1899., 1. 
Aleksa Vancaš pokopan je na groblju Mirogoj u obiteljsku grobnicu ${ }^{148}$ sa suprugom Emom rođ. pl. Kiepach od Haselberga (Krapina, 1857. - 23. kolovoza 1917.) i sestrom Belom pl. Vancaš (1861. - 1879.) $)^{149}$

\section{ANTUN PL. VANCAŠ (ZAGREB, 14. VELJAČE 1867. - ZAGREB, 27. LISTOPADA 1888.)}

Naglašeno jake emocionalne veze među članovima obitelji Vancaš iskazale su se u dirljivo brižnom odnosu i čuvanju sjećanja na prerano preminulog mlađeg brata Antuna, čiji je životopis Josip Vancaš napisao pred kraj svojega života. ${ }^{150}$

Odmalena slabašnog i boležljivog, otac ga je po završenoj nižoj gimnaziji 1880. poslao u Gospodarsku školu u Križevcima, u nadi da će sa završenom šumarskom strukom ojačati u prirodi i na svježem zraku. Iako nije bila njegov izbor, krotak i poslušan, školu je završio dobrim uspjehom i, ponovno po očevoj želji, upisao agrikulturu u Beču. Međutim, radi njegove iznimne ljubavi prema glazbi i skladanju, otac mu je odlučio udovoljiti. Vraća se u Zagreb i s velikim zanosom otpočinje pripreme za upis na bečki konzervatorij. Glazbenu teoriju, harmoniju, kontrapunkt i osnove kompozicije učio je kod Franje Kuhača, ${ }^{151}$ a glasovir kod M. Fabkovića. Nakon ovako ozbiljnih priprema upisao je bečki konzervatorij, koji je za dvije godine završio izvrsnim uspjehom. ${ }^{152} \mathrm{Na}$ prijedlog prof. Kuhača, s kojim je, pun nevinog mladenačkog povjerenja i iskrenog poštovanja, imao blizak odnos, kod prof. Đure Arnolda ${ }^{153}$ uči francuski jezik. Od rujna 1888. pohađa pariški Konzervatorij u razredu čuvenog Julesa Masseneta

148 Pored grobnice obitelji brata Josipa.

149 Podatak s nadgrobnog spomenika Alexe Viktora pl. Vancaša.

150 Životopis je pohranjen $u$ arhivi Glazbenog zavoda Hrvatske, god. 1931./32., br. 143 (prema: F. BILIĆ, Život Antuna Vancaša, 123); Hrvatski glazbeni zavod (Osobni fond, HR-HDA/IM 311, http://arhinet.arhiv.hr/details.aspx?ItemId=4_311, posjećeno 11.9. 2019.).

151 Franjo Ksaver Kuhač (Osijek, 1834. - Zagreb, 1911.), etnomuzikolog i glazbeni povjesničar, klavirski pedagog i zborovođa, koji je zapisivao, proučavao i promicao narodnu glazbu kao temelj suvremenog glazbenog stvaralaštva (Hrvatski biografski leksikon, LZMK, http://hbl.lzmk. hr/clanak.aspx?id=10872, posjećeno: 11. 2. 2019.), što je prenio i na mladog Antuna, s kojim je njegovao iskreno prijateljstvo, o čemu svjedoči sačuvana prepiska, kao i Kuhačevo djelo „Uspomene na Antuna Vancaša", Vienac, XX/1888., br. 46 i 47, 730 - 734, 746 - 750.

152 Franjo Bılıć, Život Antuna Vancaša, 119 - 131.

153 Đuro Arnold (1853. - 1942.), čiji su predci doselili iz Švicarske, prvi je doktor filozofije na Sveučilištu u Zagrebu (1880.), od 1896. redoviti profesor, dekan Filozofskog fakulteta te rektor Sveučilišta (1899./1900.). Dopisni je član JAZU od 1891., a redoviti od 1899. Predsjednik Matice hrvatske bio je od 1902. do 1909., a počasni član Društva braće hrvatskog zmaja od 1924. Arnold, Đuro, Hrvatski biografski leksikon, http://hbl.lzmk.hr/clanak.aspx?id=856, posjećeno 10. 9. 2019. 
(1842. - 1912.), profesora skladateljstva. Svojom je darovitošću, strastvenom posvećenošću i ljubaznošću već na prvoj godini studija stekao naklonost prof. Masseneta, koji ga je uveo u otmjeno pariško društvo. ${ }^{154} \mathrm{O}$ životu u Parizu, nadama i raspoloženjima, u pismima je izvještavao brata i osobito sestru Emu, koja je od 1885. vodila očevo kućanstvo. ${ }^{155}$ Kako je bila 15 godina starija od njega, povjeravao joj se u trenutcima osamljenosti, kriza i neizvjesnosti kao što bi majci, bez koje je ostao ne navršivši ni dvanaest godina života. U tim pismima „javlja se lik ljubazna, čedna i poslušna te neobično nadarena i marljiva mladića koji neobično voli glazbu i vrlo ozbiljno shvaća zadaću umjetnika; mladića pred čijom sudbinom zato nije moguće ostati nepristran". ${ }^{156}$

Sušica, od koje je dugo pobolijevao, na drugoj je godini studija znatno uznapredovala. Nakon dvomjesečnog boravka u austrijskom lječilištu i kod nećakinje Josipe Kukuljević na dobru Kostel kraj Jaske, ${ }^{157}$ preminuo je u 22 godini života. ${ }^{158}$ Ostavio je pedesetak skladbi (za zborove, solo popijevke, glasovirske skladbe) s kojima je stekao mjesto u povijesti hrvatske glazbe. Najznačajniji su mu Slavenski plesovi (1887.), uvertira za orkestar Zvonimir (1888.) te Križevačka koračnica, ${ }^{159}$ koju je „po hrvatskih narodnih napjevih Kuhačeve Sbirke južno slov. nar. popjevaka skladao i visokorodjenoj gospodji Pauli barunici Vraniczany Dobrinović rodj. pl. Kiepach posvetio“. ${ }^{160}$

154 F. Bilić, Život Antuna Vancaša, 126.

155 F. Bilić, Život Antuna Vancaša, 126. Nakon što joj je 1882. preminuo suprug Josip Thierry, iz Delnica je s djecom došla k ocu Antunu u Zagreb, koji je živio sam.

156 F. Bilić, Život Antuna Vancaša, 119.

157 F. BILIĆ, Život Antuna Vancaša, 129.

158 „Mladi pokojni vještak mislio je i na Bosnu; marljivo je radio oko znamenitog djela - misi - koja bi se prigodom posvete naše katedrale imala pjevat... al' eto nadođe smrt i prekinu život i s njim sve snove njegove..." Viestnik, Vrhbosna (Sarajevo), br. 22, 15. 11. 1888. Vijest o smrti objavio je i Sarajevski list u br. 116 od 31. 10. 1888.

159 Prodajni oglas Sveučilišne knjižnice Franje Župana, Hrvatska vila, br. 23, 6. 6. 1885., 8: Križevačka četvorka: op. 1, Naklada Akademičke knjiž. Lav. Hartmana (Kugli i Deutsch).

160 Barunica Paula (1856. - 1892.) bila je kći veleposjednika Marcela Kiepacha od Haselberga (1813. - 1887.) iz Križevaca (Narodne novine, br. 298, 31. 12. 1887., 5), tajnika tamošnje podružnice Hrvatsko-slavonskog gospodarskog društva. (Razvitak i rad hrvatsko-slavonskoga gospodarskog družtva od god. 1841. do 1883., Narodne novine, br. 20, 24. 1. 1880., 5) Bila je udana za baruna Vladimira Eugena Vranyczanyja - Dobrinovića iz Križevaca (1845. - 1929.), čiji je otac Nikola (1804. - 1876.) bio brat Ambroza Vranyczanyja - Dobrinovića (1801. 1870.), hrvatskog gospodarstvenika i političara, jednog od osnivača ilirske Čitaonice (1838.), predsjednika Matice hrvatske (1851. - 1858.) i prvog hrvatskog ministra financija (za bana Jelačića), koji je financijski pomogao osnivanje JAZU (HAZU) i Kazališta. Paula i Vladimir su 1882. sagradili dvorac Laduč kod Zaprešića s prostranim perivojem. (Više o obitelji u: Veličanstveni Vranyczanyjevi. Umjetnički, povijesni i politički okvir života jedne plemićke obitelji, Katalog izložbe, ur. Marina Bagarić, Zagreb, 2016.; Dorotea JENDRIć, Vranyczanyjevi - priča o 


\section{JOSIP PL. VANCAŠ U DRUŠTVENOM I KULTURNOM ŽIVOTU SARAJEVA}

Razmatranje obiteljske sredine bilo je nužan okvir za odgovor na pitanje: tko je, zapravo znameniti arhitekt Josip pl. Vancaš? Pitanje je to koje se nameće u svjetlu njegove izuzetne stručne, društvene, kulturne, gospodarske i političke aktivnosti kroz 38 godina njegova života i rada u Sarajevu. Po prvi puta iznesena jedna vrst anatomije obitelji Vancaš potvrdila je stajalište da je potekao iz ugledne intelektualne hrvatske plemićke obitelji, kako smo vidjeli, jakih veza među svojim članovima, što je zasigurno u temeljima i kasnije sređenog vlastitog obiteljskog života. Uz mnoge talente koje je posjedovao i obiteljske uzore, rano je iskazao potrebu za društvenošću i mnogostranim društvenim djelovanjem, koje će u najboljem smislu ostvariti u Sarajevu.

Osnovnu školu i realnu gimnaziju Josip Vancaš pohađao je u Zagrebu. Kako je već u ranoj mladosti iskazao sklonost ka glazbi i društvenosti, i on je stjecao izobrazbu kod Franje Kuhača. U roditeljskoj kući je sa svoja dva brata i Vladojem Dukatom ${ }^{161}$ složio pjevački kvartet, a kako je već kao realac dobro svirao glasovir i orgulje, zamjenjivao je profesora Strnada na đačkim misama u zagrebačkoj crkvi sv. Katarine. ${ }^{162}$ Praznike je provodio kod sestre Marije u Našicama, čiji je suprug Alojz barun Thierry ondje bio sudac. ${ }^{163}$ „I tu je složio dvostruki kvartet, što su ga pjevači izveli u crkvi. “164 Tijekom studija u Beču je s Hrvatskim akademskim društvom „Velebit“ stvorio zbor od trideset pjevača, kojemu je dirigirao na svečanom koncertu što ga je u počast hrvatskim rodoljubima 23. travnja 1879. priredilo bečko Družtvo hrvatskih tehnika, u kojem je Vancaš od 1879. odbornik, a

plemićkoj obitelji u vihoru hrvatske povijesti, Vijenac, br. 580, 25. 5. 2016., http://www.matica. $\mathrm{hr} / v i j e n a c / 580 / v r a n y c z a n y j e v i-p r i c a-o-p l e m i c k o j-o b i t e l j i-u-v i h o r u-h r v a t s k e-p o v i j e s t i-25699 /$, posjećeno 30. 9. 2019.). Supruga Antunova brata Alekse, Ema rođ. Kiepach od Haselberga, bila je kći Marcelova brata Nestora (1811. - 1882.), odnosno Paulina stričevična. (Ante RaIć, Nestor Kiepach od Haselberga, pl., https://www.geni.com/people/Nestor-Kiepach-od-Haselberga$\mathrm{pl} / 6000000038672237273$, posjećeno 3. 10. 2019.).

161 Vladoje Dukat (1861. - 1944.), hrvatski književni povjesničar, filolog i jedan od utemeljitelja anglistike u Hrvatskoj, član HAZU (JAZU) od 1938. Ima mjesta pretpostavci da je u osnovi njihova druženja činjenica da je njegov otac Vjekoslav bio poštanski činovnik, a i da je šest razreda gimnazije polazio u Zagrebu. (Igor Gostr, Istraživanja Vladoja Dukata na području hrvatske filologije, književne povijesti i anglistike, Radovi Leksikografskoga zavoda „Miroslav Krleža“, knj. 2, Zagreb, 1992., 100, http://www.lzmk.hr/images/radovi2/igor\%20gosti\%20istrazivanja\%20 vladoja\%20dukata\%20na\%20podrucju\%20hrvatske\%20filologije\%20knjizevne\%20povijesti\%20 i\%20anglistike.pdf, posjećeno 14. 3. 2019.)

162 A. Makanec, Josip pl. Vancaš Požeški, 3.

163 M. D., Thierry.

164 A. Makanec, Josip pl. Vancaš Požeški, 3. 
od 1881. i predsjednik. ${ }^{165}$ Društvo je s „Velebitom“11. srpnja 1879. u Beču priredilo „svečani komers u slavu prenosa Preradovićevih ostanaka u materu zemlju“.166

Arhitektonski odjel bečke Technische Hochschule završava 1881. odličnim uspjehom. Usavršavanje u listopadu iste godine nastavlja na Akademiji likovnih umjetnosti u Beču kod znamenitog profesora Friedricha von Schmidta, koji ga, cijeneći njegov talent i sposobnosti, preporučuje za izradu projekta sarajevske katedrale: „Ministar Kállay želi da u Bosni sagradi crkvu, pa sam odmah pomislio na vas. Ta vi ste Hrvat, a Sarajevo i Zagreb duhovno su jedno, nije li tako?"“167

Preporuke s kojima je došao, upoznavanje s Kállayem, najznačajnijim upraviteljem Bosne i Hercegovine (1882. - 1903.), a osobito s prvim vrhbosanskim nadbiskupom dr. Josipom Stadlerom (1881. - 1918.), s kojim će ostvariti blisku dugogodišnju suradnju i prijateljstvo, ${ }^{168}$ opredijelili su Vancaša, kojemu nije manjkalo ambicija i poslovnog duha, da prekine studij na Akademiji i započne projektantsku djelatnost. Ostvario je uistinu sjajnu profesionalnu karijeru. Ovlaštenim civilnim arhitektom za $\mathrm{BiH}$ s uredovnim sjedištem u Sarajevu imenovan je 5. svibnja 1889., ${ }^{169}$ građevinskim savjetnikom 3. lipnja 1906., ${ }^{170}$ a 13. lipnja 1911. dodijeljeno mu je najviše zvanje građevinskog nadsavjetnika. ${ }^{171}$ Poput strica dr. Alekse, s nesmanjenom radnom energijom i nakon umirovljenja (13. srpnja 1918.) nastavio je stručno, društveno i gospodarsko djelovanje. ${ }^{172}$

Prema osobnoj evidenciji, ${ }^{173}$ izvanredno vrijedan i uistinu golem Vancašev opus broji preko 240 projekata i realizacija, među kojima: 102 stambena objekta, 70 crkava, 12 zavoda i škola, 10 državnih i općinskih zgrada, 10 banaka, 7 palača, 6 hotela i kavana, 6 tvornica, 7 interijera i oltara, 10 pregradnji i adaptacija. ${ }^{174}$ Uglavnom su rađeni za Sarajevo i druge gradove u zemlji, ali i u Hrvatskoj,

165 Društvo je utemeljeno 1871. pod imenom „Družtvo jugoslovenskih tehnika“. Nakon izlaska Srba, a onda i Slovenaca, 31. prosinca 1872. mijenja naziv u „Družtvo hrvatskih tehnika“ (Primorac, br. 17, 30. 12. 1875., 3). Društvo počinje javno djelovati od 29. studenog 1873. (Ljetopis družtva hrvatskih tehnika u Beču, Primorac, br. 14, 2. 2. 1877., 2).

166 Male viesti, Galeb (Bakar), br. 14., 15. 7. 1879., 3.

167 Josip VANCAš, Kako sam kao arhitekt došao u Bosnu, Večernja pošta, br. 2724., 12. 7. 1930., 9.

168 Kao arhitekt i savjetnik Vrhbosanske nadbiskupije (do rujna 1921. godine), bio je u čestom i izravnom kontaktu s nadbiskupom dr. Josipom Stadlerom, uspješno realizirajući ambiciozni program izgradnje Nadbiskupije. Njihovi su odnosi imali i osobnu, prijateljsku crtu. Tako je prigodom proslave srebrnog pira Vancaševa obitelj primila sv. pričest pod sv. misom u nadbiskupovoj kapelici. (Srebrni pir, Hrvatski dnevnik, br. 291, 16. 12. 1910., 3). Također, Vancaš je bio predsjednik Priređivačkog odbora za obilježavanje zlatne mise nadbiskupa Stadlera. (Pedeset godina misništva nadbiskupa Stadlera, Sarajevski list, br. 105, 14. 5. 1918., 3).

169 Zvanično, Sarajevski list, br. 64, 31. 5. 1889., 1.

170 Zvanično, Sarajevski list, br. 74, 27. 6. 1906., 1.

171 Zvanično, Sarajevski list, br. 137, 27. 6. 1911., 1.

172 Autobiografska zabilješka.

${ }_{173}$ Autobiografska zabilješka.

174 Autobiografska zabilješka. 
Sloveniji i današnjoj Italiji. Ovdje treba istaknuti da je narudžba projekta kod najuglednijeg arhitekta bila vidljiv simbol društvenog statusa i stvar prestiža. Također treba napomenuti i da je svoje veliko znanje i bogato iskustvo Vancaš kao honorarni profesor prenosio na učenike sarajevske Srednje tehničke škole (od njezina osnutka 1889. do 1898.), ${ }^{175}$ a onda i na Preparandiji (1898. - 1908.). ${ }^{176}$

Poput strica dr. Alekse, bio je veoma angažiran na polju strukovnog organiziranja. Velike su njegove zasluge za osnivanje Tehničkog kluba za Bosnu i Hercegovinu, 1. prosinca 1896. Od početka je odbornik Kluba, predsjednik u četiri jednogodišnja mandata (1908. - 1912.), a od 1911. počasni član. ${ }^{177} \mathrm{Klub}$ mu je u povodu proslave trideset godina stručnog rada 23. studenog 1913. priredio počasnu večer u elitnom sarajevskom Hotelu Evropa, kojoj su nazočili i brojni pozvani gosti. ${ }^{178}$ Kako je veza s njegovom najužom domovinom Hrvatskom bila snažna, Vancaš je bio i član Društva hrvatskih inženjera i arhitekata u Zagrebu.

Živio je sređenim građanskim životom u obiteljskoj jednokatnoj palači u centru Sarajeva (Mula Mustafe Bašeskije 9), u čijem je prizemlju bio prostrani atelijer. Sa suprugom Marijanom Czák de Koronavár (1861. - 10. listopada 1942.) vjenčao se u Beču 16. svibnja 1885., a iduće im se godine rodio sin Alfred (8. lipnja 1886. - 11. prosinca 1955.). Sudeći prema onodobnom sarajevskom tisku, ni supruga ni sin, bankovni činovnik, nisu se eksponirali u javnosti. ${ }^{179}$

U Sarajevo se doselio 10. ožujka 1884. i kroz sve vrijeme, do povratka u Zagreb 16. rujna 1921., poput strica dr. Alekse, aktivan je sudionik i predvodnik u javnom, društvenom, kulturnom i političkom životu grada i zemlje. Koliko je u tome od početka bio uspješan, posvjedočio je i arheolog i povjesničar dr. Ćiro Truhelka (1865. - 1942.), koji je kao odličan student ${ }^{180}$ preporučen ministru Kállayu za kustosa Zemaljskog muzeja u Sarajevu, zapisao da mu je dr. Isidor

175 Autobiografska zabilješka; Spomenica prigodom proslave 40 godina opstanka Državne Tehničke srednje šole u Sarajevu 1889-1929, Sarajevo, 1929.

176 Autobiografska zabilješka.

177 Jahresbericht des Technischen club in Sarajevo, Sarajevo, 1912.

178 Tehnički klub o Vancaševoj 30-godišnjici, Sarajevski list, br. 252, 24. 11. 1913., 2; Vancaševa slava u Tehničkom klubu, Hrvatski dnevnik, br. 271, 26. 11. 1913., 3.

179 Nalazimo tek podatak da je Marijana pl. Vancaš darovala $50 \mathrm{~K}$ za orgulje Marijine crkve u Sarajevu (Darovi, Hrvatski dnevnik, br. 291, 16. 12. 1910., 3). Neobarokna crkva Kraljice sv. Krunice na Banjskom brijegu sagrađena je 1911. po Vancaševu projektu.

180 Profesor opće povijesti bio mu je Natko Nodilo (1834. - 1912.), prvak Narodne stranke u Dalmaciji, prvi urednik zadarskog Narodnog lista (1862.), rektor Sveučilišta u Zagrebu (1890. - 1891.), čija je kći Marija 1901. postala supruga prim. dr. Janka viteza Thierryja (1874. - 1938.), dugogodišnjeg fizika zagrebačke županije i osnivača hrvatske venerologije, inače sina Josipove sestre Eme (1852. 1942.). Nakon što mu je otac, Josip vitez Alois Thierry (1849. - 1882.), kotarski sudac u Delnicama, preminuo po povratku iz Bosne, gdje je sudjelovao u okupaciji kao austrijski časnik, Janko je s majkom živio kod djeda Antuna pl. Vancaša. (Josip Franjo Alois Thierry vitez (plemić), kotarski 


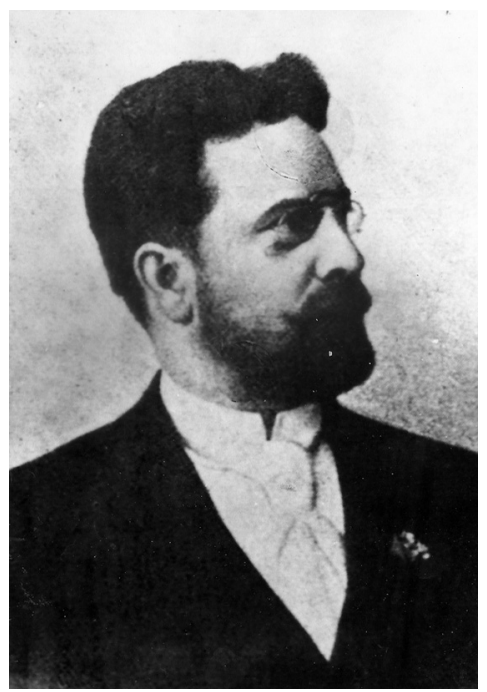

SLIKA 1. Josip pl. Vancaš (Arhiv Republičkog zavoda za zaštitu spomenika kulture i prirode $\mathrm{BiH}$, Sarajevo)

Kršnjavi pred polazak 1886. osim nekoliko utjecajnih političkih dužnosnika preporučio i Vancaša, „među najpopularnijim ličnostima tadašnjeg Sarajeva““ ${ }^{181}$

Josip Vancaš je od 1896. do 1913. bio zastupnik i predsjednik Građevinskog odbora u Gradskom zastupstvu Sarajeva, naredne dvije godine podnačelnik Sarajeva, a u ratnim uvjetima savjetnik vladinog komesara (1915. - 1918.). Za zasluge u razvitku grada, odlukom Gradskog zastupstva od 3. prosinca 1908., jedna sarajevska ulica nazvana je njegovim imenom. ${ }^{182}$ Kao zastupnik u Saboru Bosne i Hercegovine (1910. - 1915.) ${ }^{183}$ ispred Hrvatske katoličke udruge, ${ }^{184}$ čiji je predsjednik bio, na učinkovit način pokretao je i realizirao strategijski važna pitanja zemlje i svojeg hrvatskog naroda. Uz punu podršku nadbiskupa Stadlera kao glavnog ideloga Hrvatske katoličke udruge, pridonio je zaštiti i promoviranju interesa Hrvata, buđenju, jačanju, njegovanju i širenju hrvatske svijesti unutar procesa stvaranja moderne hrvatske nacije.

sudac u Delnicama, Matica hrvatska - ogranak u Čabru, https://www.maticahrvatska-cabar.hr/ delnice_leksikon_9.php, posjećeno 7.11.2019.; M. D., Thierry).

181 Ćiro TruhelKa, Uspomene jednog pionira, Zagreb, 1942., 33.

182 Sjednica Gradskog zastupstva, Sarajevski list, br. 146, 6. 12. 1908., 3.

183 Patent o raspuštanju Sabora car Franjo Josip je izdao u Beču, 6. veljače 1915., Sarajevski list, br. 42 (Izvanredno izdanje), 10.2. 1915.

184 „Hrvatska katolička udruga će raditi na ostvarenju programa od 26. lipnja 1894. tj. stojeći na temelju državnoga prava i narodnog načela, radit će svima zakonitim sredstvima“ da se sav hrvatski narod, pa tako i u Bosni i Hercegovini, „sjedini u jedno samostalno državno tijelo u okviru Habzburške monarhije“. (Hrvatska katolička udruga odobrena, Hrvatski dnevnik, br. 164, 25. 7. 1911., 1). 
Društveni je život u Bosni do dolaska Austro-Ugarske bio nerazvijen, uglavnom sveden na kućna druženja. Kako bi se zadovoljile kulturne potrebe civilnih i vojnih doseljenika, opravdao povjereni mandat pacifikacije i kulturnog razvitka zemlje te prevladao animozitet domaće javnosti prema novoj upravi, ubrzo nakon okončane okupacije (1878.) i smjene vojne civilnom upravom, priređivani su koncerti vojnih orkestara, a vladini dužnosnici i, u manjoj mjeri, domaći uglednici organiziraju kućna sijela sa zabavama i gostovanjima glazbenika iz Monarhije. Sudjelovanjem kao solist na dobrotvornim koncertima, Vancaš se od početka afirmirao u tadašnjoj društvenoj eliti. ${ }^{185}$

U vrijeme pokušaja stvaranja, političkim interesima motivirane, univerzalne „bosanske nacije“ kao pokušaja ignoriranja nacionalnih karakteristika i zatiranja nacionalne svijesti, afirmacija kulturnog identiteta kao nositelja nacionalnog identiteta dobiva osobit značaj. Prepoznavši to, na temeljima baštinjenih obiteljskih vrijednosti, posebice strica dr. Alekse, zaslužnog ilirca, Josip Vancaš svojim javnim istupima, osnivanjem i vođenjem institucija, ustrajno djeluje u smjeru uspostavljanja suvremenog kulturnog i nacionalnog identiteta Hrvata u Bosni i Hercegovini.

U prosincu 1885. pokreće inicijativu za osnivanje Muškog pjevačkog društva, prvog u Sarajevu. ${ }^{186} \mathrm{Na}$ prvoj glavnoj skupštini 6. ožujka 1887. Vancaš je izabran za prvog zborovođu, ${ }^{187}$ što je ostao do 1908., kada se okreće gospodarskom i političkom djelovanju. Od 1889. je potpredsjednik Društva, ${ }^{188}$ a 1893. izabran je za počasnog člana. ${ }^{189}$ Podupirano od utjecajnih političkih ličnosti, Društvo je, pod Vancaševim vodstvom, sa šest do sedam koncerata godišnje, sukladno proklamiranim ciljevima, djelovalo „kao stožer i pionir harmonične družebnosti i da pomoću pjesme djeluje i na humanitarnome polju“. ${ }^{190}$ Iako je prema odobrenim Pravilima „jednostrano nacionalno djelanje“ bilo isključeno, osim izvođenja njemačke i češke vokalne glazbe, zbor je izvodio i djela hrvatskih umjetnika, ${ }^{191}$ među kojima i skladbe u hrvatskom narodnom duhu Josipova brata Antuna. U znak sjećanja, njegovu namjenski skladanu Ave Mariju, premda nedovršenu,

185 Dobrotvorni koncert, Sarajevski list, br. 146, 21. 12. 1884., 3; Dobrotvorni koncert, Sarajevski list, br. 2, 11. 1. 1885., 2.

186 Pjevačko društvo, Sarajevski list, br. 132, 20. 11. 1885., 3.

187 Muško pjevačko društvo, Sarajevski list, br. 27, 9. 3. 1887., 3.

188 Muško pjevačko društvo, Sarajevski list, br. 39, 3. 4. 1889., 4.

189 Iz društava, Sarajevski list, br. 33, 21. 3. 1894., 3.

190 Društveni život, Večernji Sarajevski list, br. 258, 27. 11. 1911., 3. Za četvrt stoljeća u humanitarne svrhe Društvo je priložilo $20.000 \mathrm{~K}$.

191 „Za zasluge ovog društva za gojenje hrvatske pjesme i izvedbu mnogih njegovih skladbi“, Ivan pl. Zajc Društvu je posvetio svoju Hrvatsku himnu, što je u pismu Vancašu „osobito laskavim riječima popratio“ (Muško pjevačko društvo, Hrvatski dnevnik, br. 46, 26. 2. 1906., 5). 
uvrstio je za izvođenje na prvoj svečanoj misi prigodom posvećenja sarajevske katedrale 14. rujna 1889., kada je pod Vancaševim ravnanjem sudjelovalo i Muško pjevačko društvo. ${ }^{192}$ Djela svoga preminulog brata uvrstio je i za izvođenje na velikoj dobrotvornoj zabavi održanoj 1. siječnja $1917 .{ }^{193}$

Za promicanje hrvatske kulture, od značaja je Vancašev rad u Upravnom vijeću Društvenog doma u Sarajevu. ${ }^{194}$ Vijeće je odlučivalo o repertoaru i zahvaljujući njegovu radu organizirana su tada najznačajnija kulturna zbivanja u Sarajevu, a time i u cijeloj zemlji. Na prvoj, konstituirajućoj sjednici 4. siječnja 1898. ${ }^{195}$ Vancaš je izabran za tajnika osmočlanog Vijeća, ${ }^{196}$ od 1901. je potpredsjednik, a od 29. 9. 1905. predsjednik Upravnog vijeća, na čijim je sjednicama redovito i aktivno sudjelovao. Radi preopterećenja stručnim radom, brojnim društvenim i napose političkim obvezama, na sjednici upraviteljstva pod njegovim predsjedanjem održanoj 1. 5. 1907. „Zahvaljuje se na svojoj časti kao predsjednik izjavljujući da mu nije nikako moguće dalje ovu dužnost obavljati pošto je preokupiran svojim privatnim dužnostima“. ${ }^{197}$ Prihvatio je izbor za potpredsjednika i na tom će položaju ostati do kraja rada Društvenog doma, 1919. godine. Kao i svugdje, i ovdje je svojim ugledom i autoritetom značajno utjecao na umjetnički repertoar, pa je tako na svečanostima prigodom otvorenja novosagrađene zgrade Društvenog doma gostovalo Hrvatsko narodno kazalište iz Zagreba s osam predstava. Društveni dom otvoren je 2. siječnja 1899. „naročito u tu svrhu spjevanim prologom" hrvatskog pjesnika Silvija S. Kranjčevića. ${ }^{198}$ Vancaševe zasluge kao organizatora najbolje je iskazao komentar Sarajevskog lista nakon jedne operne večeri: „Ovake krasne muzikalne predstave može u Sarajevu samo jedan tako darovit, vješt i neumoran umjetnik da aranžira kakav je arhitekt Josip pl. Vancaš." ${ }^{199}$ Aktivno djelovanje uprave Društvenog doma nastavljeno je i u teškim ratnim uvjetima. Među ostalima, Hrvatsko narodno kazalište iz Osijeka

192 Posvećenje rimo-katoličke katedrale, Sarajevski list, br. 110, 15. 9. 1889., 2.

193 Velika dobrotvorna zabava, Sarajevski list, br. 25, 25. 1. 1917., 2. U obimnom izvještaju je i kratak životopis Antuna pl. Vancaša, kao još jedan vidljiv izraz čuvanja sjećanja na mlađeg brata.

194 Društveni dom je od 1922. godine Narodno kazalište/pozorište.

195 Zapisnik sjednice upraviteljstva zadruge društvenog doma održane 4. siječnja 1898. u sjedničkoj dvorani Zemaljske banke, Upravno vijeće Društvenog Doma - Sarajevo, Historijski arhiv Sarajevo, Sign. UVDD-579 (dalje: HAS - UVDD-579); Društveni dom, Sarajevski list, br. 4, 12. 1. $1898 ., 3$.

196 Prvi predsjednik bio je dvorski savjetnik Kosta Hörmann, a blagajnik Nikola Berković, potpredsjednik Zemaljske banke za BiH (HAS - UVDD-579).

197 I Sarajevski list (br. 56, 12. 5. 1907., 3) prenio je da je „građ. savjetnik Josip pl. Vancaš zbog službenog preopterećenja otklonio ponovno predsjedništvo u direkciji ovoga društva“.

198 Zapisnik sjednice od 24. 12. 1898., HAS - UVDD-579.

199 Operna večer, Sarajevski list, br. 33, 21. 3. 1906., 2. 
je tijekom cijelog mjeseca lipnja 1918. gostovalo s operom i operetom u velikoj dvorani Društvenog doma. ${ }^{200}$

Odmah nakon što je, po uzoru na srednjoeuropske zemlje, u Sarajevu 26. prosinca 1898. osnovan elitni Gospodski klub (Herrenclub), Vancaš je od siječnja 1899. njegov član. ${ }^{201}$ Kako je to bio međunarodni klub „ponajviše s njemačkim jezikom", ${ }^{202}$ Vancaš s dr. Milanom Prelogom i još šest odbornika 15. prosinca 1905. osniva Hrvatski klub u Sarajevu sa svrhom okupljanja hrvatske inteligencije, a bio je namijenjen i ženama, koje su se tu sastajale u posebno uređenoj prostoriji. Već početkom naredne godine Klub je imao stotinu članova iz činovničkih, učiteljskih i građanskih krugova. ${ }^{203}$

Prvi predsjednik bio je dr. Ćiro Truhelka, dok je Vancaš bio odbornik, ${ }^{204}$ potom potpredsjednik, a od 6. prosinca 1912. i predsjednik Kluba. ${ }^{205}$ Mnogo više od zabave i razonode, bio je to važan oblik društvenog života, kojega do tada nije bilo. ${ }^{206} \mathrm{Klub}$ je, među ostalim, često organizirao i gostovanja hrvatskih umjetnika. Za veliki doprinos snaženju socijalnih veza sarajevskih Hrvata, njegovanju i razvitku hrvatske kulture i nacionalne svijesti, a osobito za angažiranja na zbližavanju s hrvatskim narodom Banske Hrvatske, Vancašu je, prigodom proslave trideset godina njegova uspješnog arhitektonskog rada, Klub posvetio svoju prvu zabavu održanu 29. studenog 1913. u vlastitim klupskim prostorijama novosagrađene palače Hrvatskog društva Napredak, „dupkom pune općinstva iz najotmjenijih sarajevskih krugova“.207

Napretkova palača izgrađena je zahvaljujući prvenstveno angažiranju Josipa Vancaša koji je od 1909. do 1915. bio predsjednik Društva Hrvatski dom u Sarajevu, utemeljenog sa svrhom da osigura sredstva za izgradnju palače za sva sarajevska hrvatska društva i klubove. Inicijativu je još 1904. pokrenulo hrvatsko pjevačko društvo „Trebević“, 208 ali je odaziv bio nedovoljan. Tijekom 1910. Vancaš je uputio javne apele Hrvatima u zemlji, Banskoj Hrvatskoj i Sloveniji, kao i „svim ovdje živućim Slavenima“ da kao utemeljitelji, dobrotvori i novi članovi pruže potporu izgradnji Hrvatskog doma. Ovdje se, kao autentična ilustracija stalne Vancaševe usmjerenosti k očuvanju i afirmaciji hrvatskog identiteta, donose navodi iz njegova

200 Zapisnik sjednice od 29. 4. 1918., HAS - UVDD-579.

201 Gospodski klub u Sarajevu, Sarajevski list, br. 154, 28. 12. 1898., 3.

202 Ć. Truhelka, Uspomene jednog pionira, 121.

203 Hrvatski klub u Sarajevu, Sarajevski list, br. 14, 4. 2. 1906., 2.

204 Ć. Truhelka, Uspomene jednog pionira, 121.

205 Hrvatski klub u Sarajevu, Sarajevski list, br. 259, 1. 12. 1912., 3.

206 U uvjetima kulturne i komunikacijske izolacije u prethodnom, osmanskom razdoblju, obitelj, susjedstvo i crkva bili su jedina mjesta društvenosti, a franjevački samostani jedine kulturne institucije.

207 Vancaševa proslava u „Hrvatskom klubu“, Sarajevski list, br. 258, 1. 12. 1913., 2.

208 Osnovano je 1894., ali je „Hrvatsko“ u nazivu Zemaljska vlada odobrila tek 1898. godine. 
apela za nacionalnu solidarnost u izgradnji Doma „koji bi bio ne samo stjecište svih sarajevskih hrvatskih društava, nego bi imao služiti i kao vidljiv znak hrvatske narodnosti u ovim krajevima“. Posebno naglašava „da je podignuće doma snažno sredstvo za ojačanje narodne svijesti“ i da „mi Hrvati koji smo ovdje kod kuće, a Sarajevo je glavni grad u kojem valja da se [...] i vidljivim znakom domaćina prikazujemo“.209 Osobnim ugledom, vrijednim poznanstvima i prijateljstvima s utjecajnim osobama priskrbio je potrebna sredstva i palača je sagrađena. On i njegova strina Josipa pl. Vancaš, udovica dr. Alekse, su među utemeljiteljima, a kao dobrotvor pristupila je zagrebačka Prva hrvatska štedionica. ${ }^{210}$

$\mathrm{Uz}$ to što je obavljao samostalnu projektantsku djelatnost, poslovnu poduzetnost potvrdio je i kao direktor Bosansko-hercegovačkog gradevnog dioničkog društva (od 1907.), član Društva industrijalaca Bosne i Hercegovine (od 1909.) i na koncu savjetnik ravnateljstva Privilegirane zemaljske banke za Bosnu $i$ Hercegovinu (od 1917.).

Kršćanski svjetonazor potvrdio je u teškom ratnom razdoblju, kada je pomagao organizacijski, ali i osobnim prilozima. $S$ dr. Brunom Curinaldijem, ${ }^{211}$ poglavarom zdravstva u Zemaljskoj vladi, u srpnju 1914. osniva Bosanskohercegovačko zemaljsko društvo za pomoć $i$ dobrovoljnu sanitarnu njegu u ratu, a u slučaju opće nevolje i u mirno doba ${ }^{212}$ (Crveni križ Bosne i Hercegovine). Na konstituirajućoj skupštini Društva održanoj 30. srpnja 1914. Vancaš je izabran za dopredsjednika Muškog odbora, darujući i osobni prilog od $500 \mathrm{~K}$. ${ }^{213}$ Društvo je 7. siječnja 1915. dobilo „previšnje priznanje“ cara Franje Josipa za blagotvorno djelovanje „kao izraz patriotizma i požrtvovnosti“.214 Godine 1915. sarajevskoj gradskoj Uboškoj zakladi darovao je $100 \mathrm{~K}$, a Dječjem domu obitelji rezervista $50 \mathrm{~K} .{ }^{215} \mathrm{Uz}$ to, bio je i član Vijeća za prehranu naroda u Bosni i Hercegovini. ${ }^{216}$

209 Hrvatski dom u Sarajevu, Edinost (Trst), 16. 1. 1910., XI; Hrvatski dom u Sarajevu, Hrvatska rieč (Šibenik), 26. 1. 1910., 3.

210 Hrvatski dom, Sarajevski list, br. 168, 10.6. 1915., 2. Najmanji iznos priloga za dobrotvora bio je $500 \mathrm{~K}$, a za utemeljitelja $100 \mathrm{~K}$, priloženih odjednom ili u roku jedne godine.

211 Dr. Curinaldi rođen je 1864. u uglednoj zadarskoj obitelji. Nakon završenog bečkog Medicinskog fakulteta, pomoćni je liječnik u Gradskoj bolnici u Zadru. Od 1879. do 1912. je kotarski liječnik u Mostaru, čiji je počasni građanin od 1889. Unatoč svojoj vezanosti za Mostar, nakon imenovanja šefom Zemaljskog saniteta morao se 1912. preseliti u Sarajevo, gdje je ostao do kraja života (1944.). Više u: Ivica VUČAK, Dr. Bruno Curinaldi (1854. - 1944.): od Zadra preko Mostara do Sarajeva, AMHA - Acta medico-historica Adriatica, sv. 7, br. 1, 2009., 19 - 38, https://hrcak.srce.hr/47405, posjećeno 12.3.2019.

212 Pravila, Sarajevski list, br. 167, 31. 7. 1914., 1.

213 Gradske vijesti, Sarajevski list, br. 167, 31. 7. 1914., 2.

214 Previšnje priznanje, Sarajevski list, br. 19, 19. 1. 1915., 3.

215 Poklon gradskoj sirotinji, Sarajevski list, br. 234, 27. 8. 1915., 3.

216 Sarajevski list, br. 108, 21. 5. 1918., 3. 
Za zasluge u radu Crvenog križa i opće osobno zalaganje na humanitarnom polju 1916. dodijeljeni su mu Oficirski križ austrijskog Crvenog križa i Medalja pruskog Crvenog križa III. razreda, ${ }^{217}$ a 7. veljače 1916. za osobite zasluge u ratu car Franjo Josip odlikovao ga je Viteškim križem Reda Leopolda. ${ }^{218}$ Za Vancašev obiteljski profil vrijedno je ovdje napomenuti i da je njegovu sinu Alfredu, bankovnom činovniku, za rad na humanitarnom polju car 1915. dodijelio Srebrnu počasnu medalju Crvenog križa s ratnom dekoracijom. ${ }^{219}$

Ljudske kvalitete Vancaš nije iskazivao samo prema ljudima. U dvorištu zagrebačkog Oktogona 1899. postavio je reljefnu spomen-ploču psu, kojega je prihvatio, dobivši zauzvrat Plutovu potpunu odanost. ${ }^{220}$

Ugled koji je imao ilustriraju i podatci da je bio član gradske deputacije na pokopu ministra Benjamina Kállaya u Budimpešti (1903. ${ }^{221}$ te predsjednik Odbora za podizanje spomenika caru Franji Josipu I. (1908.). ${ }^{222}$ Ubrzo nakon atentata, kao podnačelnik grada iznio je prijedlog Gradskom zastupstvu da se na mjestu tragične smrti Franza Ferdinanda postavi spomen-ploča i predložio nacrt, što je prihvaćeno, ${ }^{223}$ i ploča je 1916. postavljena na zid današnjeg Muzeja Sarajevo 1878. - 1918.

Prosvjedi, neredi i odmazde, koje su nakon izvršenog atentata u Sarajevu poprimile takve razmjere da je na području grada i kotara proglašen prijeki sud, poslužili su za obračun $s$ Vancašem u novoj državi, s drugačijom političkom konstelacijom. Kraljevsko državno odvjetništvo u Sarajevu optužilo ga je da je 29. lipnja 1914. „raspaljujućim govorima u Sarajevu huškao masu na izgrede i neprijateljstva“ protiv pripadnika srpske nacionalnosti, čime da je „počinio zločinstvo sukrivnje u zločinstvu javnoga nasilja“. ${ }^{224}$ Po završenoj istrazi, nakon tri mjeseca provedena $u$ istražnom zatvoru, na sudskoj raspravi pred Okružnim sudom u Sarajevu od 7. do 11. lipnja 1919., Vancaš je riješen svih optužbi i odmah oslobođen. Njegovo nijekanje krivnje isticanjem da je „blage naravi“, potvrdile

217 Odlikovani, Sarajevski list, br. 281, 20. 10. 1916., 2 - 3. Istodobno je dr. Curinaldi odlikovan Medaljom pruskog Crvenog križa III. razreda.

218 Zvanično, Sarajevski list, br. 40, 17.2. 1916., 2.

219 Službeno, Sarajevski list, br. 234, 1. 10. 1915., 3.

220 Ispod reljefa psa s natpisom „Gradjevni pas Pluto“ stoji ploča: „Za vrijeme gradnje Oktogona dolutalog psa prigrlili su graditelj i arhitekt zgrade Josip pl. Vancaš. Postao je vjeran prijatelj i čuvar gradilišta, na tom je zadatku i tragično poginuo. Arhitekt i graditelji podigoše ovu ploču u spomen svom čuvaru i prijatelju.“ U potpisu natpisne ploče lijevo stoji „Josip pl. Vancaš 1899.“, a desno „Grad Zagreb 2013.“.

221 Gradska deputacija, Sarajevski list, br. 82, 15. 7. 1903., 1.

222 Spomenik caru - kralju u Sarajevu, Sarajevski list, br. 154, 25. 12. 1908.

223 Izvanredna sjednica Gradskog zastupstva, Sarajevski list, br. 269, 5. 11. 1914., 4.

224 Iz sudnice, Jugoslavenski list, br. 129, 7. 6. 1919., 3. 
su i izjave svjedoka, advokata dr. Nikole Mandića da je Vancaš „stereotipno koncilijantan čovjek“ i srpskog trgovca i podnačelnika Sarajeva Riste Hadžidamjanovića, čija je radnja također bila demolirana, „da uprkos tome što je stajao pod sugestijom klerikalaca i frankovaca, nije pokazivao nikakve vjerske i plemenske mržnje“.225

Već prije toga, na sjednici Općinskog odbora Sarajeva 11. siječnja 1919. donesena je odluka o promjeni imena sarajevskih ulica, pa je Vancaševa ulica nazvana Skerlićeva. ${ }^{226}$ Vancaš je kasnije prokomentirao kako je to „bez posebnoga razloga poništeno“. ${ }^{227}$

Moralo je ovo biti veliko razočarenje za Vancaša, koji je Sarajevu i njegovu svestranom napretku posvetio cijeli svoj radni vijek. I bez ove vremenske distance, to je prepoznatljivo u slici grada i neodvojivo od njegova kulturnog i društvenog života na prijelomu dvaju stoljeća. Bila je to, možda i očekivana posljedica tradicionalnog podozrenja domaćeg stanovništva spram doseljenika i netrpeljivosti prema uspješnima. Imao je Vancaš takvo iskustvo i kada je kao zastupnik na sjednici Sabora 1911. u povodu tzv. kuferaškog pitanja, u podužem govoru „pravdao“ sebe i druge doseljenike, jer „nastoje da svoje snage mogu posvetiti što bolje ovim zemljama".228

U novim društvenim i političkim okolnostima Josip Vancaš odlučuje napustiti Sarajevo. Kuću je ustupio Savezu Hrvatskih seljačkih zadruga i s obitelji se 16. rujna 1921. vratio u Zagreb, ${ }^{229}$ gdje je kupio dvokatnicu u Kačićevoj br. $17 .{ }^{230}$

U povodu 70 godina života, 1929. izabran je za počasnog člana bečkog društva arhitekata Wiener Bauhütte, počasnog člana društva Braća hrvatskog zmaja i dopisnog člana JAZU (HAZU).

Preminuo je u Zagrebu 15. prosinca 1932. u 22,30. ${ }^{231}$ Pokopan je na groblju Mirogoj. ${ }^{232}$

225 Afera Vancaš pred sudom, Jugoslavenski list, br. 130, 8. 6. 1919., 2.

226 Naziv Vancaševa ulici je vraćen svibnju 1994. (A. An., Vancaševa ulica, Oslobođenje, 5. 10. 1994.)

227 Autobiografska zabilješka.

228 Iz govora narodnog zastupnika Josipa pl. Vancaša u proračunskoj raspravi, Hrvatski dnevnik, br. 51, 4. 3. 1911., 2.

229 Autobiografska zabilješka.

230 Prema popisu stanova iz 1902., vlasnica kuće bila je Magdalena Kranjčan. Hartmanov sveobći popis stanova sa podpunim adresarom oblasti, ureda, obrtnika i trgovaca kralj. slobodnoga i glavnoga grada Zagreba: 1902. Elektroničko izdanje izvornika: Knjižnice grada Zagreba, 2014., http://kgzdzb. arhivpro.hr/? sitetext $=317$, posjećeno 3. 3. 2019. Prema ovome popisu, u Kačićevoj br. 16 bila je kuća znamenitog arhitekta Hermana Bolléa (Köln, 1845. - Zagreb, 1926.), a na br. 9 Zemaljska uzorna pivnica.

231 A. MaKaneC, Josip pl. Vancaš Požeški, 3.

232 Obiteljska grobnica Josipa, Marijane i Alfreda pl. Vancaš Požeški, rkt odjel, polje 9, razred II/I, broj 36. 


\section{ZAKLJUČAK}

Ishodišna namjera provedenih istraživanja bila je da se u historiografskom znanstvenom diskursu dosadašnja parcijalna saznanja o članovima obitelji Vancaš objedine i prošire, kako bi se razriješile dosadašnje nepoznanice i nedorečenosti u identificiranju čimbenika koji su utjecali na profiliranje osobnosti Josipa pl. Vancaša i sve njegove dosege.

Polazeći od znanstveno potvrđenog stajališta da su obiteljski uzori i poticaji nezamjenjivi za kognitivni i socijalni razvoj, osobni rast i životna postignuća, bilo je potrebno istražiti temeljne informacije o obitelji čiji je odvjetak i u kojoj je rastao. Kako se veza po muškoj liniji izravno uspostavlja i najpouzdanije istražuje, s ciljem obuhvaćanja svestranosti Josipa Vancaša i zauzimanja stava o njegovu stvaralačkom prostoru, $u$ radu je predstavljena obiteljska duhovna i kulturna tradicija i načinjen reprezentativni izbor djelovanja članova njegove obitelji na vertikalnoj i horizontalnoj razini. Otac Antun, pravnik, ravnatelj Hrvatskoslavonskih pošta u najvišem zvanju kr. savjetnika, bio je primjer revnosti, marljivosti, točnosti i pravednosti. Josip Vancaš baštinio je moralne zakone i vrednote i strica Janka, župnika i počasnog kanonika, pristaše ilirskog pokreta. Drugi stric dr. Aleksa, ugledni intelektualac, zaslužni hrvatski rodoljub i ilirac, kao fizik i protomedik značajan za povijest medicine u Hrvatskoj, široko i s uspjehom angažiran na stručnom, gospodarskom, društvenom, kulturnom i političkom polju, najizravnija je poveznica s navedenim društvenim angažiranjima Josipa Vancaša. I njegov deset godina stariji brat Aleksa Viktor bio je uspješan pravnik i sudac, koji je dosegnuo najviše zvanje kr. državnog nadodvjetnika.

Rezultati provedenih istraživanja nedvojbeno potvrđuju da su se silnice intelektualno orijentirane obitelji snažno izraženog hrvatskog katoličkog identiteta na najbolji način susrele u iznimno plodnom životopisu Josipa Vancaša. $\mathrm{Na}$ tim obiteljskim temeljima i s kasnijim izvanobiteljskim povezivanjima, uz veliku osobnu energiju, visoku razinu samosvijesti i samopouzdanja, ustrajnost u radu i izrazite prosocijalne kompetencije, profilirao se kao jedna od najznamenitijih i najutjecajnijih osoba u Sarajevu, Bosni i Hercegovini i šire. Predstavljeni obiteljski i osobni profil, brojna stručna, društvena i kulturna postignuća prilog su pojašnjenju fenomena Josip pl. Vancaš.

$S$ ovim vremenskim odmakom bilo je potrebno novo prepoznavanje i osvježeno otkrivanje uistinu vrijednog i neiscrpno poticajnog života i djela uraslog $u$ duhovne temelje $i$ vrhunce naše povijesti i kulture. A to je mnogo više od zasluženog sjećanja. 
Prilog 1. Rodoslovlje obitelji Vancaš

(Rodoslovlje je izrađeno na temelju autorovih istraživanja i „Rodoslovlja Vancaš“ objavljeno u F. Bilić, Život Antuna Vancaša, 131, Jutarnji list, 6. 4. 1937.)

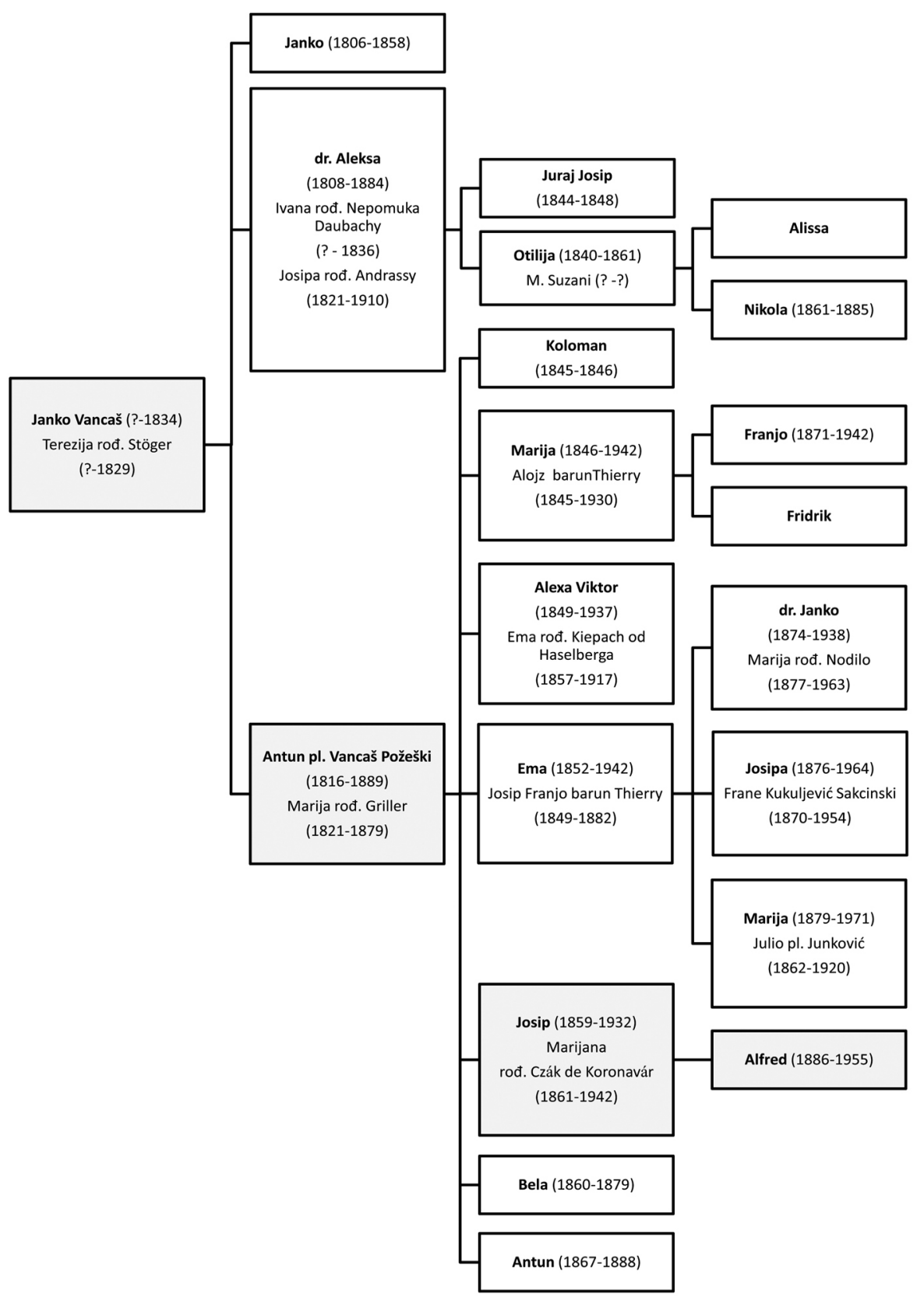




\section{IZVORI I LITERATURA}

\section{IZVORI:}

Arhiv Republičkog zavoda za zaštitu spomenika kulture i prirode BiH, Sarajevo (ARZZSK BiH). Autobiografska zabilješka Josipa pl. Vancaša (nesređeno gradivo)

Historijski arhiv Sarajevo, Arhivski fond: HAS - UVDD-579. Zapisnik sjednica Upravnog vijeća Društvenog doma u Sarajevu. Zap. 4. I. 1898. - 14. V. 1919.

Državni arhiv u Zagrebu, Arhivski fond: HR-DAZG-10 Gradsko poglavarstvo Zagreb, Gradska poduzeća, GP 1/3, http://daz.hr/svecana-povelja-oosnutku-zagrebackog-vodovoda-1878-hr-dazg-10-gradskopoglavarstvo-zagreb-gradska-poduzeca-gp-13/, posjećeno 22. 3. 2019.

Hrvatski glazbeni zavod, HR-HDA / IM 311, Nacionalni arhivski informacioni sustav, http://arhinet.arhiv.hr/details.aspx?ItemId=4_311, posjećeno 11.9.2019.

\section{OBJAVLJENI IZVORI:}

Brzoglasni imenik Nezavisne Države Hrvatske iz 1942. https://actacroatica.com/ $\mathrm{hr} /$ persona/Marija_Junkovic_1//, posjećeno 11.9. 2019.

Cesarski patent od 25. prosinca 1850. Reichsgesetzblatt 1849-1918 (kroatisch), 99 - 104, http://alex.onb.ac.at/cgicontent/alex ?aid=rsk\&datum =1851\&pa ge $=967 \&$ size $=45$, posjećeno 11.4. 2019.

Hartmanov sveobći popis stanova sa podpunim adresarom oblasti, ureda, obrtnika $i$ trgovaca kralj. slobodnoga i glavnoga grada Zagreba: 1902. Elektroničko izdanje izvornika. Knjižnice grada Zagreba, 2014., http://kgzdzb.arhivpro. $\mathrm{hr} /$ ?sitetext=317, posjećeno 3.3. 2019.

Imenik dostojanstvenika, činovnika i javnih službenika Kraljevina Hrvatske i Slavonije, Zagreb, 1917., Acta Croatica, https://actacroatica.com/hr/, posjećeno 16. 9.2019.

Imenik prautemeljiteljah, utemeljiteljah i članovah zagrebačkoga Družtva čovječnosti, Zagreb, 1868., https://digitalnezbirke.kgz.hr/?object=view\&id $=18341$, posjećeno 4. 9. 2019.

Ljetopis i imenik književnog društva Svetog Jeronima iz 1906. Pretisak povijesnog izvora. Acta Croatica, https://actacroatica.com/hr/, posjećeno 21. 9.2019.

M. D., Thierry, http://www.croeu.com/forum/index.php?topic=2825.0, posjećeno 4. 9. 2018.

Obći zagrebački Kolendar za godinu 1847., ur. Slavoljub Vrbančić, Zagreb, 1847., 220, https://books.google.hr/books?id=fedYAAAAcAAJ, posjećeno 21. 10. 2018. 
Pregled p. n. gospode pravih utemeljitelja Matice od godišta 1842., 12, Kolo, god. VI, Zagreb, 1848., Digitized by Google, pdf, https://books.googleusercontent. com/books/, posjećeno 15. 9. 2018.

Prvi adresar grada Zagreba iz 1902. Pretisak povijesnog izvora. Acta Croatica, https://actacroatica.com/hr/persona/Josipa_Vancas/, posjećeno 10.10. 2018.

Račun od Matice horvatsko-slavonske načinjen koncem godišta 1846., 14, Kolo, god. VI, Zagreb, 1848., https://books.googleusercontent.com/books/, posjećeno 15. 9. 2018.

Telefonski imenik. Direkcija Zagreb, 1938. Pretisak povijesnog izvora. Acta Croatica, https://actacroatica.com/hr/persona/Alfred_Vancas_2/, posjećeno 14. 5. 2019.

NOVINE:

Banovac (Petrinja)

Branislav (Osijek)

Carsko - kraljevske službene narodne novine (Zagreb)

Domobran (Zagreb)

Galeb (Bakar)

Hrvatska rieč (Šibenik)

Hrvatska vila (Zagreb)

Hrvatski dnevnik (Sarajevo)

Ilirske narodne novine (Zagreb)

Jahresbericht des Technischen club in Sarajevo (Sarajevo)

Jugoslavenski list (Sarajevo)

Jutarnji list (Zagreb)

Katolički tjednik (Sarajevo)

Narodne novine (Zagreb)

Novine dalmatinsko-hervatsko-slavonske (Zagreb)

Novine horvatsko-dalmatinsko-slavonske Zagreb

Pravi prijatelj naroda (Zagreb)

Oslobodenje (Sarajevo)

Sarajevski list / Večernji Sarajevski list (Sarajevo)

Sloga (Karlovac)

Sriemski Hrvat (Vukovar)

Syrmier Zeitung (Vukovar)

Vrhbosna (Sarajevo) 


\section{LITERATURA:}

Batina, Klementina, Aspekti ženskog autorstva: komparativna analiza etnološke i folklorističke građe HAZU, doktorski rad, Filozofski fakultet Sveučilišta u Zagrebu, Zagreb, 2015., http://darhiv.ffzg.unizg.hr/id/eprint/5778/1/K. Batina_PhD.pdf, posjećeno 14. 5.2019.

Belicza, Biserka, Orlić, Dubravko, Hrvatski liječnički zbor: predsjednici od 1874 do 2004., Zagreb, 2004.

Božıć, Jelena, Arhitekt Josip Vancaš. Značaj i doprinos arhitekturi Sarajeva, Zavod za udžbenike i nastavna sredstva, I. Sarajevo, 2006.

Brleković, Josip, Članstvo Matice hrvatske u prošlosti i sadašnjosti, Matica hrvatska, http://www.matica.hr/omatici/Kratka\%20povijest \%20organiziranja\%20i\%20ustrojstva\%20Mati\%C4\%8Dina\%20\%C4\%8 Dlanstva\%20(1842-2014)/, posjećeno 15. 9. 2018.

BRLEKović, Josip, Mecene i dobrotvori Matice hrvatske, Kolo, br. 3, 2017. http://www.matica.hr/kolo/534/mecene-i-dobrotvori-maticehrvatske-27577/, posjećeno 14.9. 2018.

Brozović, dr. Leander, Dr. Aleksa Vancaš (1808. - 1884.), Liječnički vjesnik, god. LXIII, br. 4, Zagreb, 1941., http://library.foi.hr/casopisi/vel/ S01101/1941/1941_00004.pdf, posjećeno 15.3.2019.

ButuRAC, Josip, Stanovništvo Požege i okolice 1700. - 1950., Zbornik za narodni život i običaje JAZU, knj. 43. Zagreb, 1967., Digitalna zbirka HAZU, https:// dizbi.hazu.hr/a/?pr=i\&id=21107), posjećeno 23. 5. 2019.

ĆEPulić, Vladimir, Kratka povijest Zbora liječnika Hrvatske, Slavonije i Međumurja. Zagreb, 1937., http://library.foi.hr/knjige/knjiga.aspx?C=2587 \&broj=1, posjećeno 12.6. 2018.

Ćosić, Vesna, Demografske i javnozdravstvene odrednice razvoja porodništva $i$ primaljstva u Slavonskom Brodu tijekom 19. stoljeća, doktorski rad, Medicinski fakultet Sveučilišta u Zagrebu, Zagreb, 2016., http://medlib.mef.hr/2607/1/ Cosic_Vesna.pdf, posjećeno 9. 11.2019.

De Canziani Jakšıć, Theodor, Protomedicus Kraljevine Hrvatske Dr. Ivan Christoph Nepomuk Daubachy de Dolje u Spomeničkoj knjižnici i zbirci Mažuranić-Brlić-Ružić. AMHA-Acta medico-historica Adriatica, sv. 8, br. 2, 2010., 214, https://hrcak.srce.hr/63532, posjećeno 11.6. 2019.

Dissertatio medica De rabie, quam annuente inclyta Facultate medica pro doctoris medicinae laurea in alma ac Cel. regia Univ. Pestiensi consequenda conscripsit Alexius Vanczáss, Croata Zagrabiensis, Artis ocularis magister. These adnexae publice defendetur in Palato Reg. Universitatis maiori M. Augusto 1832. Budae: Typis Typogr. regiae Universit. Hungaricae, 1832., digitalno izdanje, 
https://books.google.ba/books?id=PLpUAAAAcAAJ\&pg=PA1\&source=g bs_toc_r\&cad $=3 \# \mathrm{v}=$ onepage $\& \mathrm{q} \& \mathrm{f}=$ false), posjećeno 18.11.2019.

Dr. Aleksa Vancaš, Liečnički vjestnik, br. 10, 1943., 303 - 305, https://library.foi.

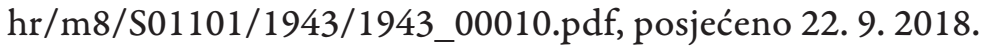

DugačKi, Vladimir, KRZNarić, Željko, Hrvatski liječnički zbor od 1874. do 2014., Zagreb, 2014., http://www.hlz.hr/pdf/knjiga-hlz.pdf, posjećeno 8. 10. 2018.

220 godina streljaštva u Zagrebu. Slike iz streljačke prošlosti, ur. Kruno Sabolić, Zagreb, 2006., http://www.zsa.hr/images/stories/monografija/monografija. pdf, posjećeno 12.12. 2018.

FILIPČIĆ, Vlatka, Grof Juraj Oršić u preporodnom pokretu, Radovi: Radovi Zavoda za hrvatsku povijest Filozofskog fakulteta sveučilišta u Zagrebu, sv. 29, br. 1, 1997., 163 - 172, https://hrcak.srce.hr/index.php?show=clanak\&id_ clanak_jezik=76980, posjećeno 11.3.2019.

GostL, Igor, Istraživanja Vladoja Dukata na području hrvatske filologije, književne povijesti i anglistike, Radovi Leksikografskoga zavoda „Miroslav Krleža", knj. 2, Zagreb, 1992., 99 - 134, http://www.lzmk.hr/images/radovi2/ igor\%20gosti\%20istrazivanja\%20vladoja\%20dukata\%20na\%20podrucju\%20 hrvatske\%20filologije\%20knjizevne\%20povijesti\%20i\%20anglistike.pdf, posjećeno 14.3.2019.

HoRvat, dr. Rudolf, Arhitekt Josip pl. Vancaš, Hrvatska revija, god. VI, br. 3, 1933., 193-195.

JENDRIĆ, Dorotea, Vranyczanyjevi - priča o plemićkoj obitelji u vihoru hrvatske povijesti, Vijenac, br. 580 25. 5. 2016., http://www.matica.hr/ vijenac/580/vranyczanyjevi-prica-o-plemickoj-obitelji-u-vihoru-hrvatskepovijesti-25699/, posjećeno 30.9.2019.

JuRIĆ, Zlatko, Vodovod u Zagrebu: od ideje do ostvarenja 1861. do 1878., Život umjetnosti, br. 60, 1998., 49 - 66, https://www.ipu.hr/content/zivotumjetnosti/ZU_60-1998_048-066_Juric.pdf, posjećeno 10.5.2019.

KAssowıtz-Cvijıć, Antonija, Josipa Vancaš, nazvana „Majčica Ilira“, Hrvatsko kolo, knj. 10, Zagreb, 1929., 41 - 85.

Kolar-Dimitrijević, Mira, Kako su narodnjaci pobijedili na izborima 1871.? (Nepoznata brošura Ivana Mažuranića?), Povijesni prilozi, Vol. 14, br. 14, Zagreb, 1995., 163-207.

Kolveshi, Željka, Upravitelji pošte u Zagrebu iz obitelji grofova Oršić Slavetičkih, u: Grofovi Oršić u Hrvatskom zagorju, ur. Vlatka Filipčić Maligec, Gornja Stubica, 1996, 35 - 40), http://www.mgz.hr/UserFiles/file/OrsicMHZ-1996.pdf, posjećeno 12.3.2019. 
Luetić, Tihana, Darovi i davatelji Arheološkom odjelu Narodnog zemaljskog muzeja u Zagrebu od 1868. do 1875. godine, Vjesnik Arheološkog muzeja u Zagrebu, sv. 34, br. 1, 2001., https://hrcak.srce.hr/25292, posjećeno 22. 6. 2019.

Makanec, Alfred, Josip pl. Vancaš Požeški, Katolički tjednik (Sarajevo), br. 52, 25. 12. 1932., 2 - 4.

Matica hrvatska 1842. - 1997., ur. Josip Bratulić, Zagreb, 2008. Biblioteka Elektronička izdanja, http://www.matica.hr/knjige/997/, posjećeno 28. 4. 2019.

Popović, Štefanija, Popis imanja Zagrebačke županije u doba ukidanja feudalnih odnosa, Radovi: Radovi Zavoda za hrvatsku povijest Filozofskog fakulteta sveučilišta u Zagrebu, sv. 28. br. 1, Zagreb, 1995., https://hrcak.srce.hr/50246, posjećeno 11.9.2018.

RoHLWEs, Johann Nicolaus, Občinskiživinvračitel ali navučanje vsakoga gospodara svoje konje, goveda, ovce, svinje, koze i cucke odkojiti, zderžavati, oveh betege spoznati i vračiti - na horvatski jezik prenešeno po Aleksi Vanczass, Zagreb, 1839., digitalna zbirka HAZU, https://dizbi.hazu.hr/a/?pr=i\&id=290794, posjećeno 8.9. 2019.

Smičiklas, Tade, Franjo Marković, Spomen-knjiga Matice hrvatske: Matica hrvatska od godine 1842. do godine 1892., Zagreb, 1892., digitalni preslik izvornika, http://www.matica.hr/knjige/matica-hrvatska-odgodine-1842-do-godine-1892-1072/\#b4, posjećeno 16. 3. 2019.

Spomenica prigodom proslave 40 godina opstanka Državne Tehničke srednje škole u Sarajevu 1889-1929., Sarajevo, 1929.

ŠT RIGA, Nika, O stotoj obljetnici smrti Josipe pl. Vancaš (1824. - 1910.), Vijenac, 437, 2. prosinca 2010., digitalno izdanje, http://www.matica.hr/vijenac/437/ majka-majcica-ilira-1367/, posjećeno 12.3. 2019.

Thaller, Dr. Lujo, Povijest medicine u Hrvatskoj i Slavoniji od god. 1770. do 1850. Karlovac, 1927., http://library.foi.hr/knjige/knjiga1.aspx?B=1\&C=X00604, posjećeno 17. 6. 2019.

TruHElKa, Ćiro, Uspomene jednog pionira, Zagreb, 1942.

VANCAš, Josip, Kako sam kao arhitekt došao u Bosnu, Večernja pošta, br. 2724., 12.7. 1930.

Veličanstveni Vranyczanyjevi. Umjetnički, povijesni i politički okvir života jedne plemićke obitelji, Katalog izložbe, ur. Marina Bagarić, Zagreb, 2016.

VUČAK, Ivica, Dr. Bruno Curinaldi (1854. - 1944.): od Zadra preko Mostara do Sarajeva. AMHA - Acta medico-bistorica Adriatica, sv. 7, br. 1, 2009., 19 - 38, https://hrcak.srce.hr/47405, posjećeno 12. 3. 2019. 
VučEvac BAJt, Vesna, Prilog razvoju veterinarstva Hrvatske u XIX. stoljeću, AMHA - Acta medico-bistorica Adriatica, sv. 5, br. 1, 2007., 55 - 70, http:// www.amha-journal.com/index.php/AMHA/article/view/232, posjećeno 6 . 9. 2019 .

\section{INTERNET IZVORI:}

Ábry, BALÁzs, Franz Anton Ludwig barun Thierry, https://www.geni.com/ people/FRANZ-Anton-Ludwig-barunThierry/6000000058028983947, posjećeno 20. 9.2019.

Crkva svete Ane, Gorica Svetojanska, http://www.jastrebarsko.hr/jastrebarsko/ kuturna_bastina/sakralni-objekti/, posjećeno 16.9.2019.

Geni, https://www.geni.com/people/, posjećeno travnja 2019.

Gradska groblja Zagreb, https://www.gradskagroblja.hr/, posjećeno travnja 2019.

Hrvatski biografski leksikon, Leksikografski zavod Miroslav Krleža, http://hbl. lzmk.hr/, posjećeno travnja 2019.

Hrvatsko-slavonsko gospodarsko društvo, Nacionalni arbivski informacijski sustav, http://arhinet.arhiv.hr/details.aspx?ItemId=3_8345, posjećeno 20. 3. 2019.

Kuća Vancaš, Ministarstvo kulture Republike Hrvatske, Registar kulturnih dobara, https://www.min-kulture.hr/default.aspx?id=6212\&kdId=405475117, posjećeno 18. 9. 2019.

LALoš, Željko, Josip Franjo Alojz Thierry (vitez), Matica hrvatska - ogranak $u$ Čabru, https://www.maticahrvatska-cabar.hr/delnice_leksikon_9.php, posjećeno 7. 11.2019.

Stare hrvatske novine, http://dnc.nsk.hr/Newspapers/Default.aspx, posjećeno tijekom 2019.

Zaklada Zamah, http://dobrotvorka.zamah.hr/, posjećeno 12. listopada 2018. 
Jelena BOŽIĆ

NEW CONTRIBUTION TO THE CURRICULUM VITAE OF JOSIP PL. VANCAŠ (1859 - 1932): FAMILY FOUNDATIONS, ROLE MODELS AND INITIATIVES OF SOCIAL AND CULTURAL ACTIVITY

\section{SUMMARY}

Historiographical literature on Josip pl. Vrancaš assessed multiple aspects of his valuable, extensive and diverse architectural opus. Besides, he was active in a wide range of activities and interests, at a high cultural level, far beyond the circumstances of that time. Having the best education, high culture, operating ability and agility as prerequisites for success, he was a driving force, an influential participant and a leader in the public, social and cultural life of Sarajevo and Bosnia and Herzegovina. The research aims to consolidate and expand into the current partial knowledge so as to resolve previous unknowns and ambiguities in identifying the factors that influenced the profiling of the personality of Josip pl. Vancaš and his achievements. To comprise his merits and properly evaluate them, the paper first gives a historiographical panorama of the renowned Croatian Vancaš family, which revealed the foundations, role models and initiatives of high achievements of his valuable and lasting inspirational life.

A research update was needed and new knowledge in the search of answers that are never unambiguous and given once and for all. Based on interpretatively absorbed facts, the drawn comparisons and conclusions resolve numerous unknowns and so far unseen issues in revealing the exceptional personality of Josip pl. Vancaš. The permanent presence of his work in our spiritual present compels us to a lasting memory. This paper also contributes to this.

Keywords: Josip pl. Vancaš, family, social and cultural activities, Croatia, Sarajevo, Austro - Hungarian monarchy. 